\title{
Ethnomedicinal plants used by local inhabitants of Jakholi block, Rudraprayag district, western Himalaya, India
}

\author{
Ankit Singh ${ }^{1}$, Mohan C. Nautiyal ${ }^{1}$, Ripu M. Kunwar ${ }^{2 *}$ and Rainer W. Bussmann ${ }^{3}$
}

\begin{abstract}
Background: Ethnomedicinal knowledge of the Indian Himalayas is very interesting because of the wide range of medicinal plants used in traditional medical practice. However, there is a danger of knowledge being lost because the knowledge sharing is very limited and passed on orally. The present study is the first ethnomedicinal study in Jakholi area of Rudraprayag district of Northwestern India. The aim of present study was to identify traditional medicinal plants used by the inhabitants to treat different ailments and document the associated knowledge of these medicinal plants.

Methods: An ethnomedicinal survey was carried out in 72 of 133 villages and alpine pastures of Jakholi block (800-4000 m asl). Door to door surveys and group discussions, applying semi-structured questionnaires were conducted with traditional healers and villagers in local language (Garhwali). Informant Consensus Factor (ICF) was computed to analyse collected ethnomedicinal data.
\end{abstract}

Results: A total of 78 species (Gymnosperms 3 species, Monocotyledons 12 and 63 Dicotyledons) belonging to 73 genera in 46 families were identified to treat 14 different ailments categories. Most dominant family is Asteraceae ( 5 species). In disease treated categories, Diseases of the skin (DE) have the highest proportion (29.55\%) followed by Gastro- intestinal disorder (GA) (25.89\%). The most life form of plants used was herb (56\%) followed by tree (23\%) while root was the most frequently used part of the plants and the traditional preparation was mainly applied in the form of paste (37\%). The highest ICF value (0.99) was found for hair ailments (HA) followed ophthalmologic complaints (OP) and mental afflictions (MA) (0.98).

Conclusions: The present study provides valuable information about traditional knowledge of medicinal plants of Jakholi Block in the Northwestern Himalaya, India. Local communities still possess large traditional knowledge of plants and their therapeutic uses and that the link of that traditional knowledge to modern research could be of importance for the isolation of new phytotherapeutic compounds leading to the development of novel therapeutic active agents. Some of the ethnomedicinal plants are facing high threats and are becoming rare, and conservation initiatives are needed to conserve them for sustainable management in the region.

Keywords: Conservation, Informant consensus factor, Medicinal plants, Sustainable use, Traditional knowledge, Western Himalaya

\footnotetext{
* Correspondence: ripukunwar@gmail.com

${ }^{2}$ Practical Solutions, Kathmandu, Nepal

Full list of author information is available at the end of the article
} 


\section{Background}

The Himalaya is a dynamic area, covering over $18 \%$ of the Indian subcontinent and harbouring about 8000 species of angiosperms, 1748 of which are used for their therapeutic properties [1]. The region has been well known for its rich ethnomedicinal flora since ancient times [2].

Plants are used since long time to cure intense chronic diseases, and also as a source of food, shelter and clothing. Due to very low expense and good results these medicinal practices are transmitted through generation to generation and still practiced in different communities. These valuable medicinal plants contain rich bioactive compounds which serve various pharmacological activity. Ethnic people depend on the plants around them to gain economic values and primary health care benefits which is based on need, observation, experience of older ethnic people, and trial and error [3]. About $65 \%$ of the Indian population depend on traditional medicine [4]. The study area is interesting due to wide geographic and climatic condition and medicinal plants diversity of Jakholi Block makes this region an especially valuable treasure home of a wide range of wild medicinal and aromatic plants. Ethnic people, shepherd and traditional medicinal practitioner (Vaidyas and Daai) inhabit within a range of 700-3800 m asl and have high knowledge of medicinal plants uses. Local wooden and stone tools are commonly used to prepare medicinal remedies. Most diseases cured by local herbalist are common problems such as respiratory diseases, aches and pains, wounds and musculoskeletal ailments. Inhabitants often use local medicinal plants without prior advice of local traditional healers because they are using these plants since generations. In these connections, the present study was carried out to provide an overview of the knowledge of medicinal plants of the local and traditional healers of Jakholi area and to evaluate the status of these useful medicinal flora for identification of new drugs for health needs and suitable source of income for livelihood of inhabitants. We hypothesize that plant use at Jakholi would show similar response to other Himalayan regions, and that the local medicinal flora would have been overharvested.

The first step of diagnosis by local healers is checking the pulse rate and heartbeat, then examining the forehead, eyes, tongue and in some cases also the urine. The body temperature and colour are major key factors to identify health problems. Medicinal plants play a vital role in the local economy and health care, and demand is increasing. Many populations of medicinal plants seem to drastically decline due to overexploitation and unsustainable harvesting. Most of the important alpine medicinal plants are becoming rare and endangered.

\section{Methods}

\section{Study area and sites}

The Jakholi Block is located between the coordinates $30^{\circ}$ $37^{\prime} 08.88^{\prime \prime}$ to $30^{\circ} 15^{\prime} 13.47^{\prime \prime} \mathrm{N}$ and $79^{\circ} 03^{\prime} 43.79^{\prime \prime}$ to $78^{\circ} 50^{\prime} 07.97^{\prime \prime}$ E (Google Earth Pro Us dept. of State Geographer 2017) in district Rudraprayag western Himalayas India. Medicinal plants sampling was done from alpine meadows of Panwali Kantha (3500 - 4000 m) to lower altitudes $(800 \mathrm{~m})$ (Fig. 1). Annual average rain fall is around $1850-2000 \mathrm{~mm}$ with temperature ranging from -5 to $15{ }^{\circ} \mathrm{C}$ in winter and 20 to $35^{\circ} \mathrm{C}$ in summer (High land to lower hills).

This study was conducted in Jakholi Block of Rudraprayag district, located in north west Uttarakhand. The total area is about $500 \mathrm{~km}^{2}$ including 133 villages [5], with a total estimated population of 74,759 (34,126 male and 40,633 female) [6]. Most of the inhabitants live in small villages, and few families are shepherds and stay mostly in alpine areas (Bugyal and Kharka) for 7 10 months a year. Most of the inhabitants are farmers. Medical facilities are rare in Jakholi block, and most of the health problems are cured traditionally by local medicine. For chronic diseases people have to travel more than $100-200 \mathrm{~km}$ from their village to get attention at health facilities. Most of the younger generation, especially men, migrate to cities in order to find employment. Women and elder people live in the villages. Inhabitants are generally belonging to three major cast group, Jajman, Brahman and Oji (about 65\%, 15\%, 20\% respectively), and Hinduism is the major religion of the inhabitants. Most people speak Garhwali, and Hindi is the secondary major language of the region. Mountain terrace farming is abundant in region, (Fig. 2a), with three crops a year: Rabi (October-April/May e.g. Wheat, Barley, Mustard), Kharif (April-October e.g. Rice, Corn), and Jayad (May-October e.g. Cucumber, Pumpkin, Beans).

\section{Data collection}

A total of 220 individuals were surveyed during the study. Among them some key participants which were experienced and rich knowledge of the medicinal flora were selected for collection and identification of local medicinal plants. All interviews were conducted after obtaining oral and verbal prior informed consents from all individual participants.

The study was conducted during October 2014 to September 2015 in randomly selected villages of Jakholi and information about local medicinal plants was also gathered from shepherds (Bakrwal) and ranchers (Maur) in the alpine regions, and their homesteads (commonly called Kharka and Maira/Chani viz. Panwali Kantha, Jadi, Koni and Matya, Fig. 2b).

Household survey was conducted using individual personal meetings and group discussions as well as field 


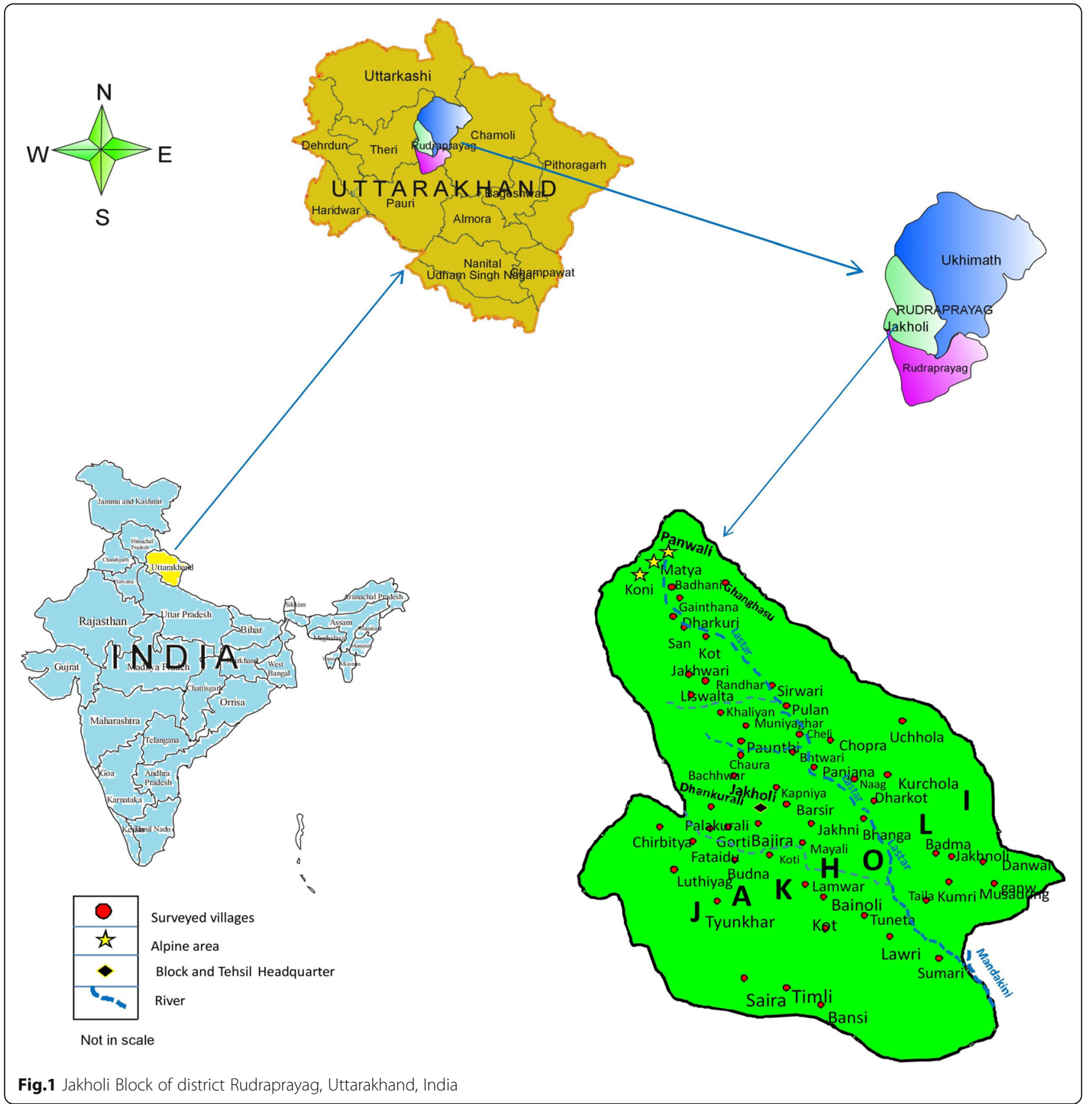

surveys [7-9]. (Fig. 2c). Questionnaires were prepared in English, but interviews were conducted in local language (Garhwali) (Appendix 1) for more convenience and accuracy. As the first author is local person of region so easy understanding and conversations with local people, together more information.

List of local medicinal plants with common name were prepared and photographs were also supplemented for more information about uses and identification. For more reliable information, diseases base questionnaires were used. Information about medicinal plants include local name, plant parts used, drug preparation, mode of administration and doses were recorded. For verification and agreement about the medicinal uses, information given by a respondent was discussed in households as group discussion.

Twenty-five key participants including 11 traditional healers, two shepherds, and 12 other local inhabitants were interviewed and their experience, knowledge of medicinal plants, methods of drug preparation, and practicing with traditional tools (Fig. 2d), etc. were recorded. Monthly schedules were made for data and plant collection including two alpine/pasture surveys were made in July and September. So the participants were 


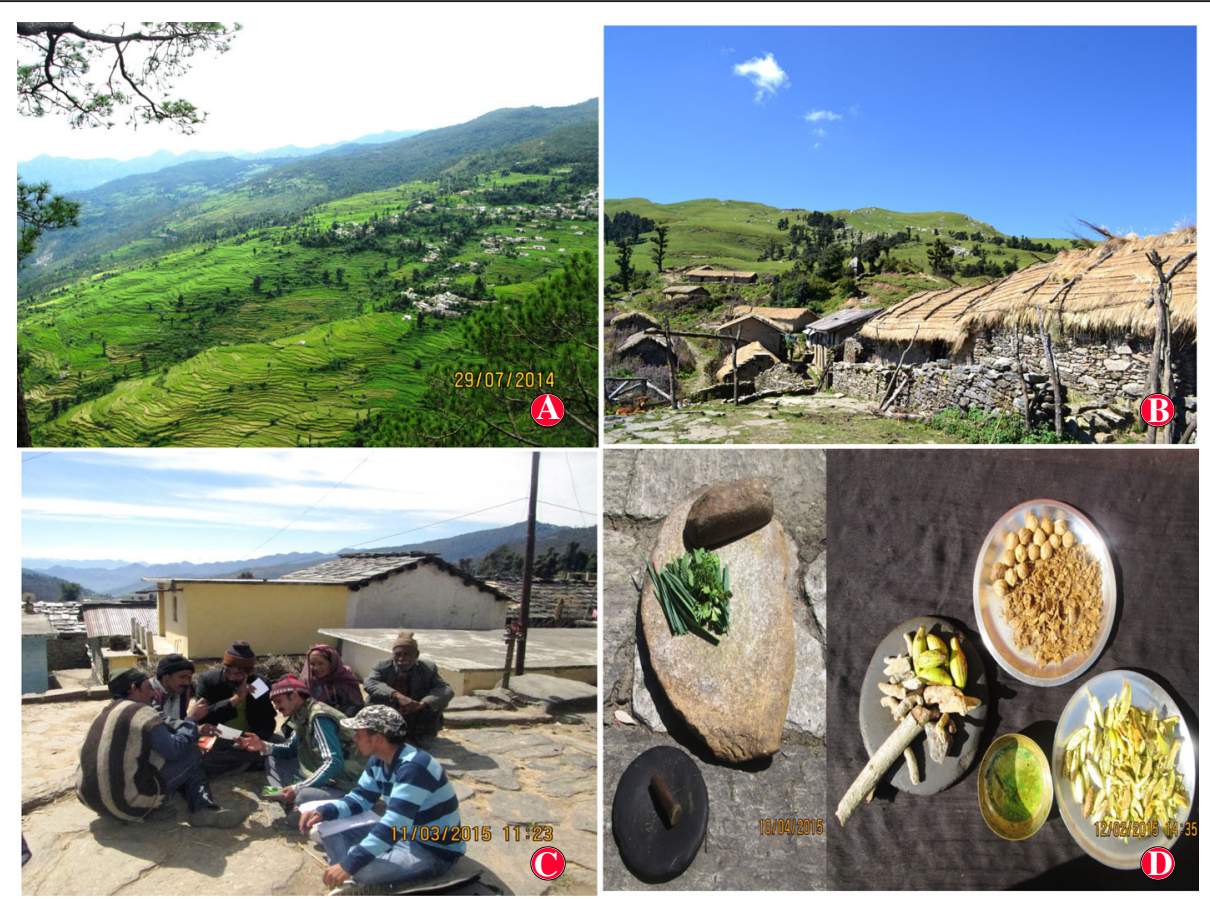

Fig. 2 Different localities and collection of information a Mountain terrace farming field $\mathbf{b}$ Panwali kantha homesteads of shepherd $\mathbf{c}$ Group discussion $\mathbf{d}$ Traditional formulation with tools

interviewed at their homes or at pastures. Medicinal plants were catalogued, and their voucher specimens were collected [10]. Dried specimens were poisoned using $0.1 \% \mathrm{HgCl}_{2}$ and ethyl-alcohol, and then mounted on herbarium sheets. Collected samples were identified with the help of a local flora $[11,12]$ and further verified through comparison with prior collections from the botanical survey of India (BSI, Northern circle Herbarium, Dehradun). Plant names were also checked in "Tropicos" http://www.tropicos.org as well as "The Plant List" (http://www.theplantlist.org), and all preserved specimens deposited at the Herbarium of HNB Garhwal University, Srinagar (HAPPRC).

\section{Data analysis}

Data were simply evaluated through informant consensus factor (ICF) described by Trotter and Logan [13, 14] and ethnomedicinal data were checked and compared with previous literature for new use reports. The ICF measures the consensus in using plants in a group about treating an illness in the study area. The ICF was calculated following:

$$
\mathrm{ICF}=N u r-N \operatorname{taxa} /(N u r-1)
$$

Where Nur refers to the number of use-reports for a particular ailment category and $\mathrm{N}$ taxa refers to the number of taxa used for a particular ailment category by all participants. ICF value ranges from 0 to 1 . It should be stressed that high ICF value (close to 1.0) indicates that relatively few taxa are used by a large proportion of participants. On the contrary low ICF value (close to 0 ) indicates a randomly use of plants by participants in treating illness.

Jaccard index (JI) is calculated by comparison of previously published studies from Himalaya and analyzed the percentages of quoted species and their medicinal uses by using the following formula:

$$
\mathrm{JI}=c \times 100 / a+b-c
$$

where "a" is the number of species of the area A, "b" is the number of species of the area $B$, and " $c$ " is the number of species common to A and B [15].

A comparison with previously published data collected from different regions was performed by evaluating percentages of the quoted species and their medicinal uses by applying Sorensen's similarity index formula [16].

$$
\mathrm{QS}=2 \mathrm{c} / \mathrm{a}+\mathrm{b} \times 100
$$

where, "a" is number of species in an area A, "b" is number of species in area B and "c" is number of species common to area $\mathrm{A}$ and $\mathrm{B}$.

\section{Results and discussion Socio-economy}

During the ethnomedicinal survey, a total of 220 people were interviewed, including shepherds at Panwali Kantha 
(3500-4000 m asl), forests and Kharka (their homesteads) during June-September 2015. The sociological profile of the participants is given in Table 1. Most participants were from 50 to 59 age group. Only 25 participants were traditional healers (Vaidyas and Daai) and the key informants for this study. Less than $9 \%$ participants were $<40$ years old, about $30 \%$ were illiterate, while many of the young practitioners hold a degree/diploma (Table 2). Almost all illiterates were $>50$ years older.

\section{Ethnomedicinal plants}

A total of 78 medicinal plant species belonging to 72 genera of 46 families including 3 gymnosperm species and 75 angiosperms (12 monocotyledons and 63 dicotyledonous) presented in (Table 3) was reported. The most represented families were Asteraceae (5 species), followed by Polygonaceae, Ranunculaceae, Rosaceae (4 species each) and Berberidaceae, Poaceae, Zingiberaceae (3 species each) (Fig. 3). Picrorhiza kurroa and Aconitum heterophyllum were common ethnomedicinal plants among all participants because these plants are culturally important as they have long been using for generations and due to their rich bioactive constituents.

\section{Life forms and plant parts used}

In present study, $56 \%$ of the species were herbs, followed by trees (23\%), shrubs (12\%), and climbers (9\%) (Fig. 4), similar to other studies carried out in Himalaya $[1,17,18]$, probably due to the presence of a wide range of rich bioactive medicinal plants in the Himalaya [19]. Traditional healers often use herbs and trees most commonly as medicine because of their easy availability [20]. Besides this, herbs can be manipulated with easiness in herbal preparation methods and extraction of bioactive compounds [21]. Less percentage of climbers might be due to less availability and difficult to harvest from huge growth of supporting material (Tree) in temperate area. Availability is found as a major reason to use the plants in Himalaya followed by cultural reason.

In present study different plant parts were used to prepare herbal preparation of drugs (Fig. 5). The common
Table $\mathbf{2}$ Literacy rate of participants

\begin{tabular}{lll}
\hline Education level & No. of individuals & Percent \\
\hline Illiterate & 64 & 29.11 \\
$1-5^{\text {th }}$ & 87 & 39.54 \\
$6-10^{\text {th }}$ & 43 & 19.54 \\
$11-12^{\text {th }}$ & 19 & 8.63 \\
$\leq 12^{\text {th }}$ & 7 & 3.18 \\
Total & 220 & \\
\hline
\end{tabular}

plants parts were roots (26\%) followed by leaves (20\%), fruit $(8 \%)$, bark and rhizome (7\%) whole plant, tuber and seeds (each 6\%), aerial part and stem or branches (each $5 \%$ ), flower, latex resin or gum, bulb, (each 1\%). Root were frequently used in folklore of Jakholi for herbal preparations similar to $[1,22]$ Root proportion is high probably due to root consist rich of active ingredients [23]. Leaves were second most useful plant part it might be due to easy availability and it is thought that leaves contain more easily extractable phytochemicals, crude drugs and many other mixtures which may be proven as valuable regarding phytotherapy [24].

\section{Mode of drug preparation and traditional tools}

Out of total 148 preparations, the herbal medicine formulations prepared according to the traditional uses as follows: paste (lepa) (37\%), juice/extract (rasa) (29\%), powder (churna, 21\%), decoction (kwath/kaada) (6\%), semi-dried (avleha) (4\%), oil (taila/ghee), solid extract (sattva), and cooked with milk (paka) (each 1\%) (Figs. 6, 7 and 8). The most frequent use of paste and juice might be due to easy preparation and effectiveness of herbal drugs. Water was commonly used as solvent if required for the preparation. Sometimes milk or honey was used as a matrix or added to increase viscosity of the preparation as reported in earlier study [25]. Paste is made by crushing plant parts and then mixing it with oil or water. Administration of dosages was taken mostly twice and thrice a day. Besides above, according to few participants the dosage depends on the age and physical appearance of the patient [24].Mostly traditional tools used by local

Table 1 Age and gender information of inhabitants and local practitioners

\begin{tabular}{|c|c|c|c|c|c|c|}
\hline \multirow[b]{2}{*}{ Age group } & \multicolumn{4}{|c|}{ Gender } & \multirow[b]{2}{*}{ No of persons } & \multirow[b]{2}{*}{ Percentage } \\
\hline & Male & Female & Vaidyas (male) & Daai (female) & & \\
\hline $30-39$ & 14 & 6 & 0 & 0 & 20 & 9.09 \\
\hline $40-49$ & 23 & 14 & 3 & 1 & 41 & 18.63 \\
\hline $50-59$ & 27 & 36 & 2 & 4 & 69 & 31.36 \\
\hline $60-69$ & 30 & 29 & 3 & 3 & 65 & 29.54 \\
\hline $70-79$ & 9 & 7 & 4 & 2 & 22 & 10 \\
\hline $80+$ & - & - & 3 & - & 3 & 1.36 \\
\hline Total & 103 & 92 & 15 & 10 & 220 & \\
\hline
\end{tabular}




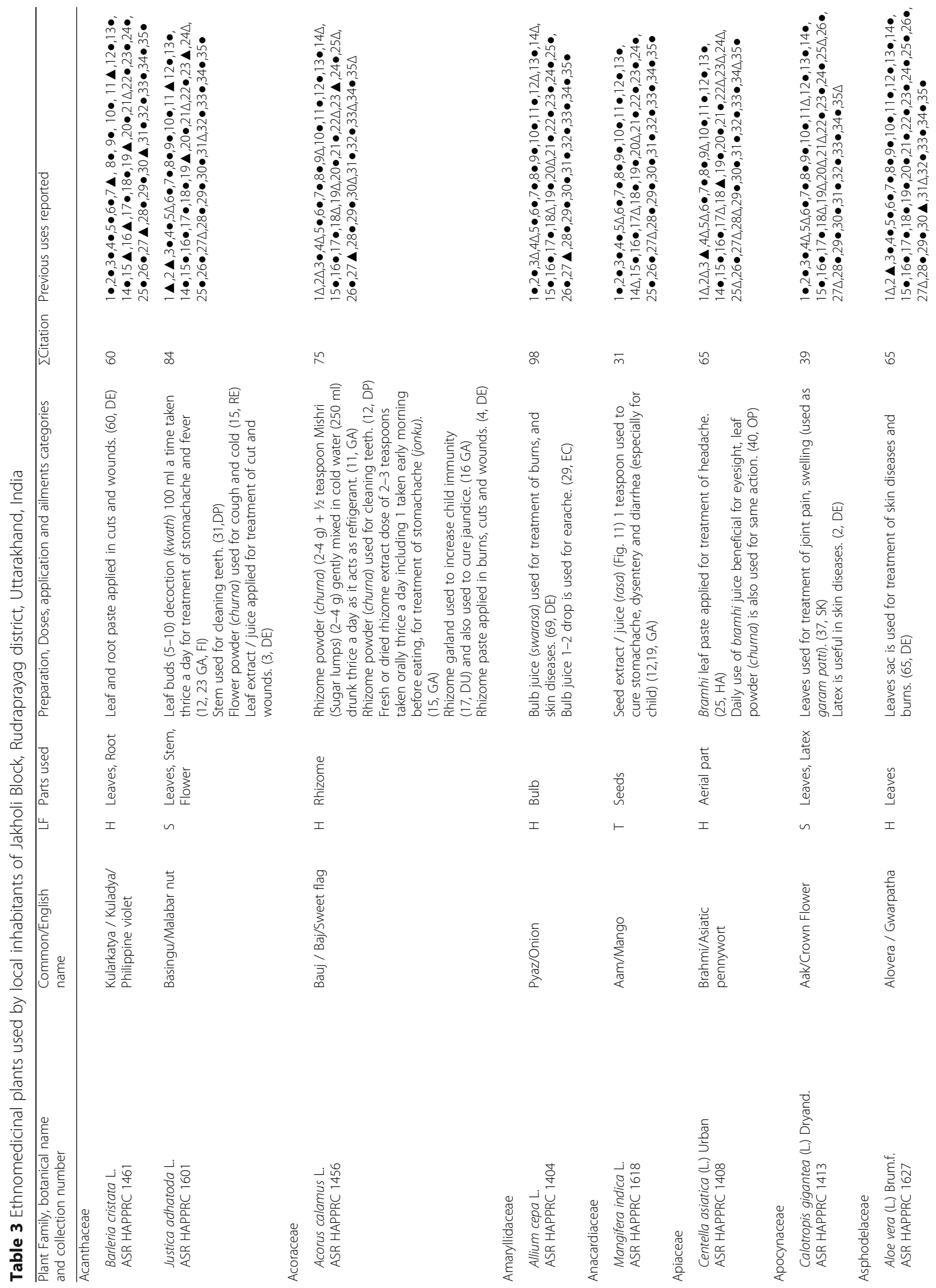




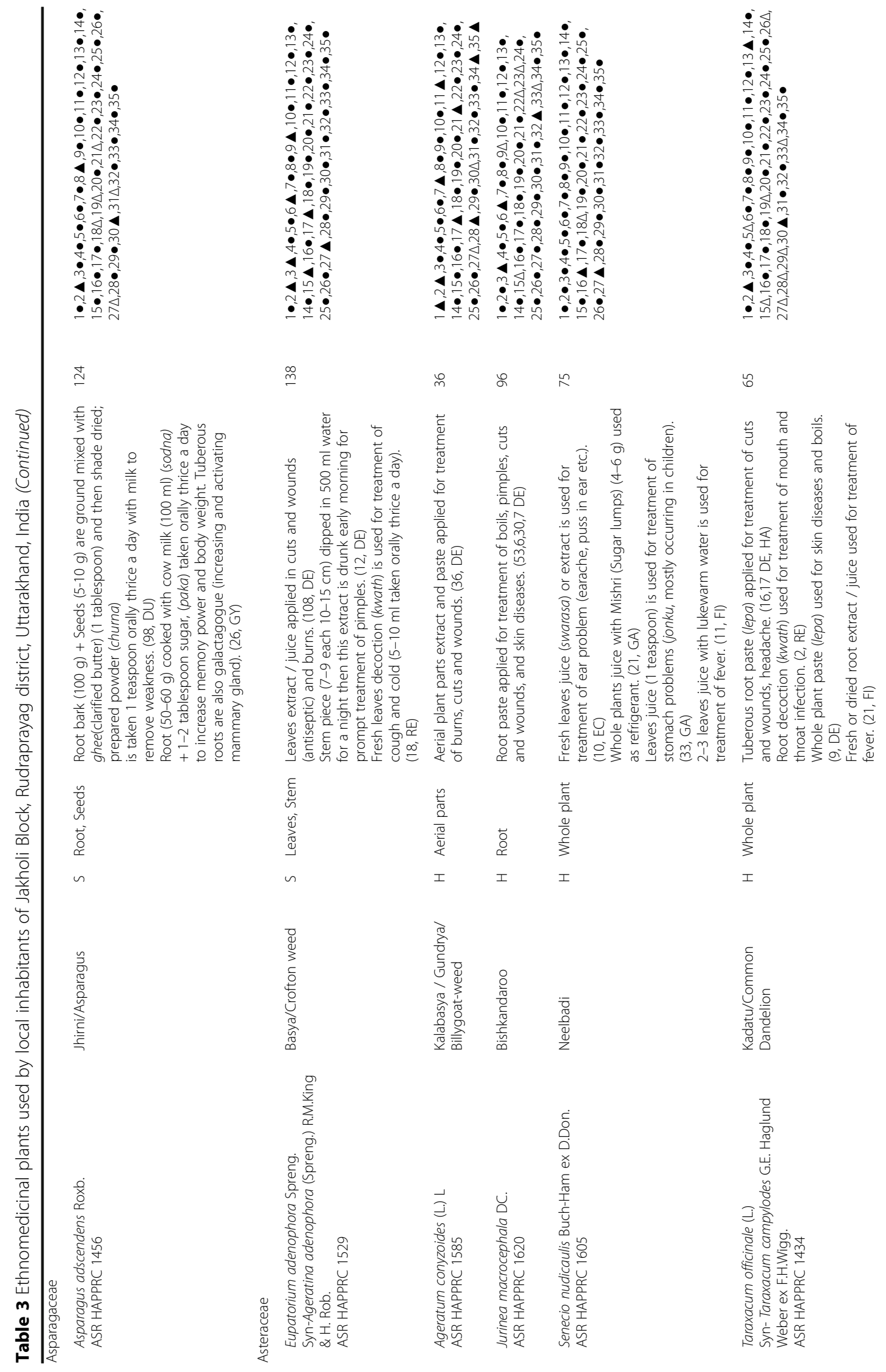




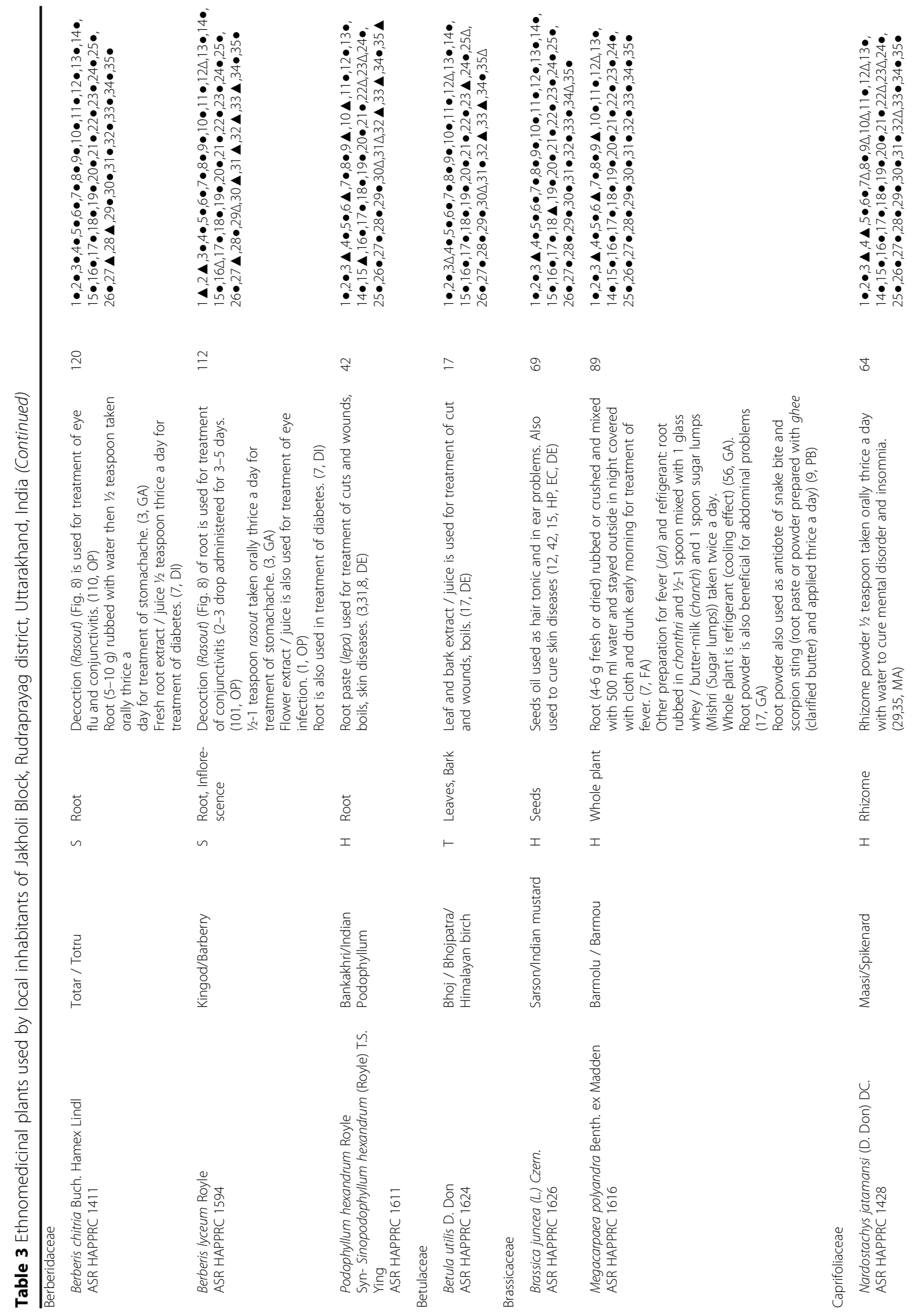




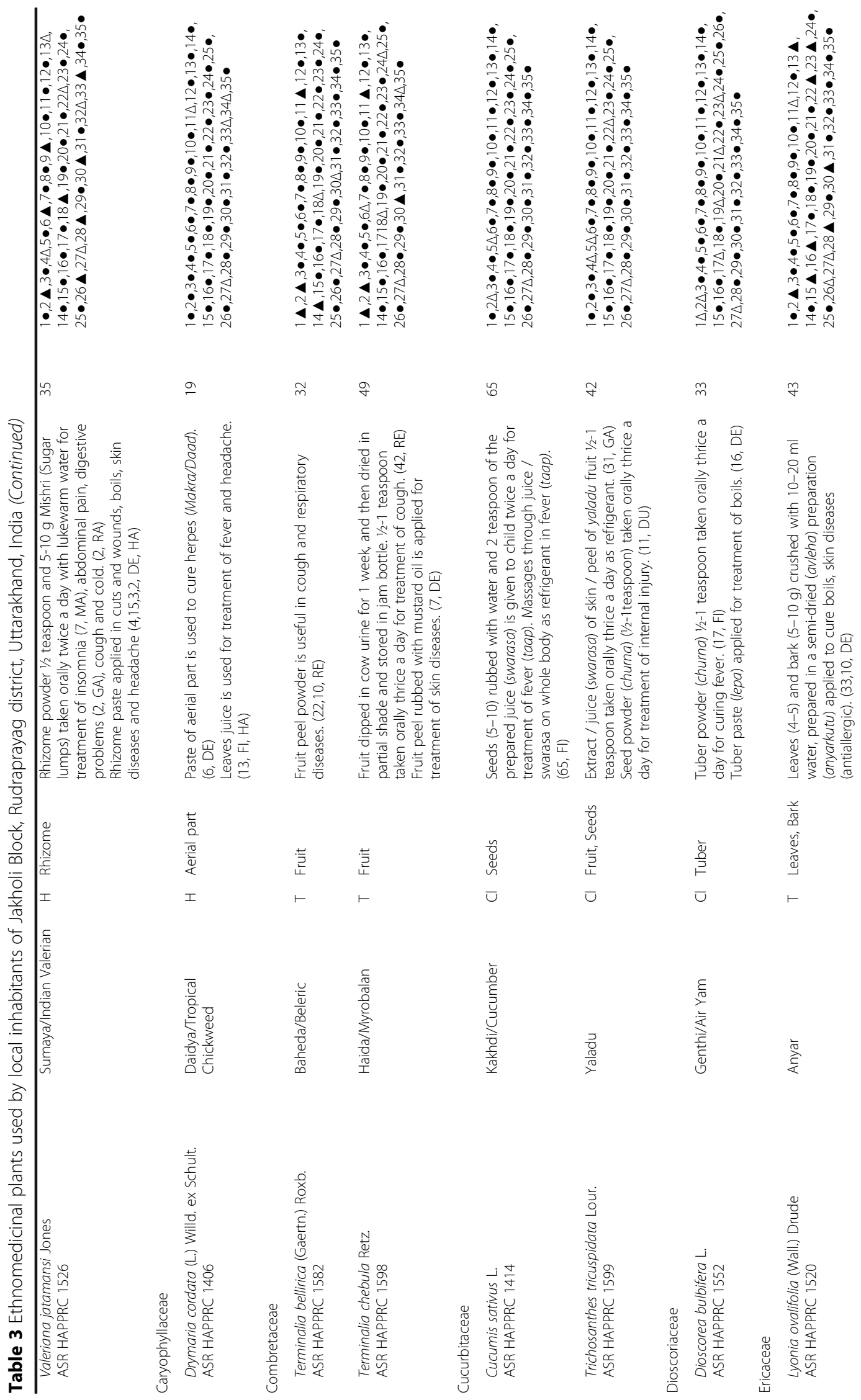




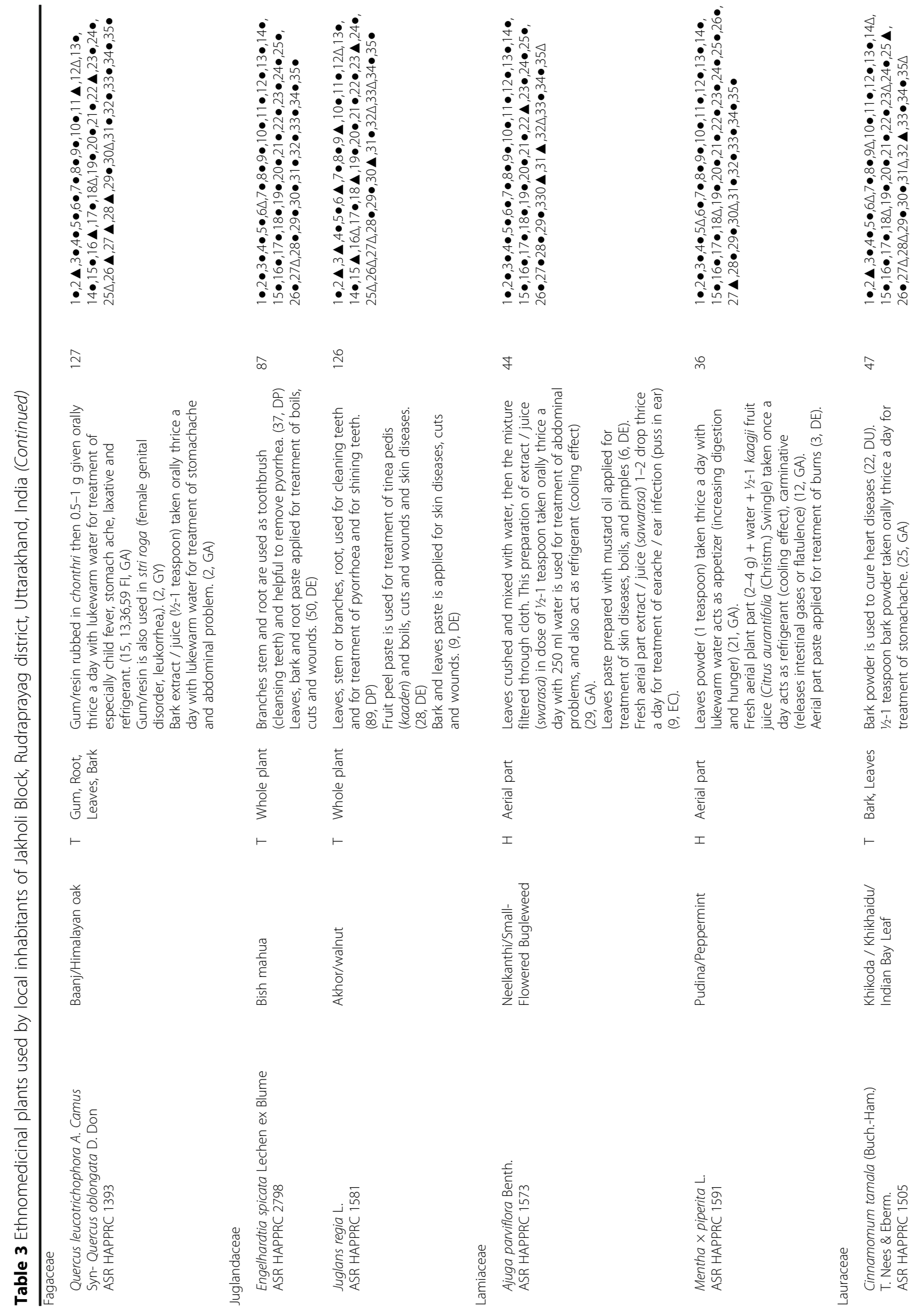




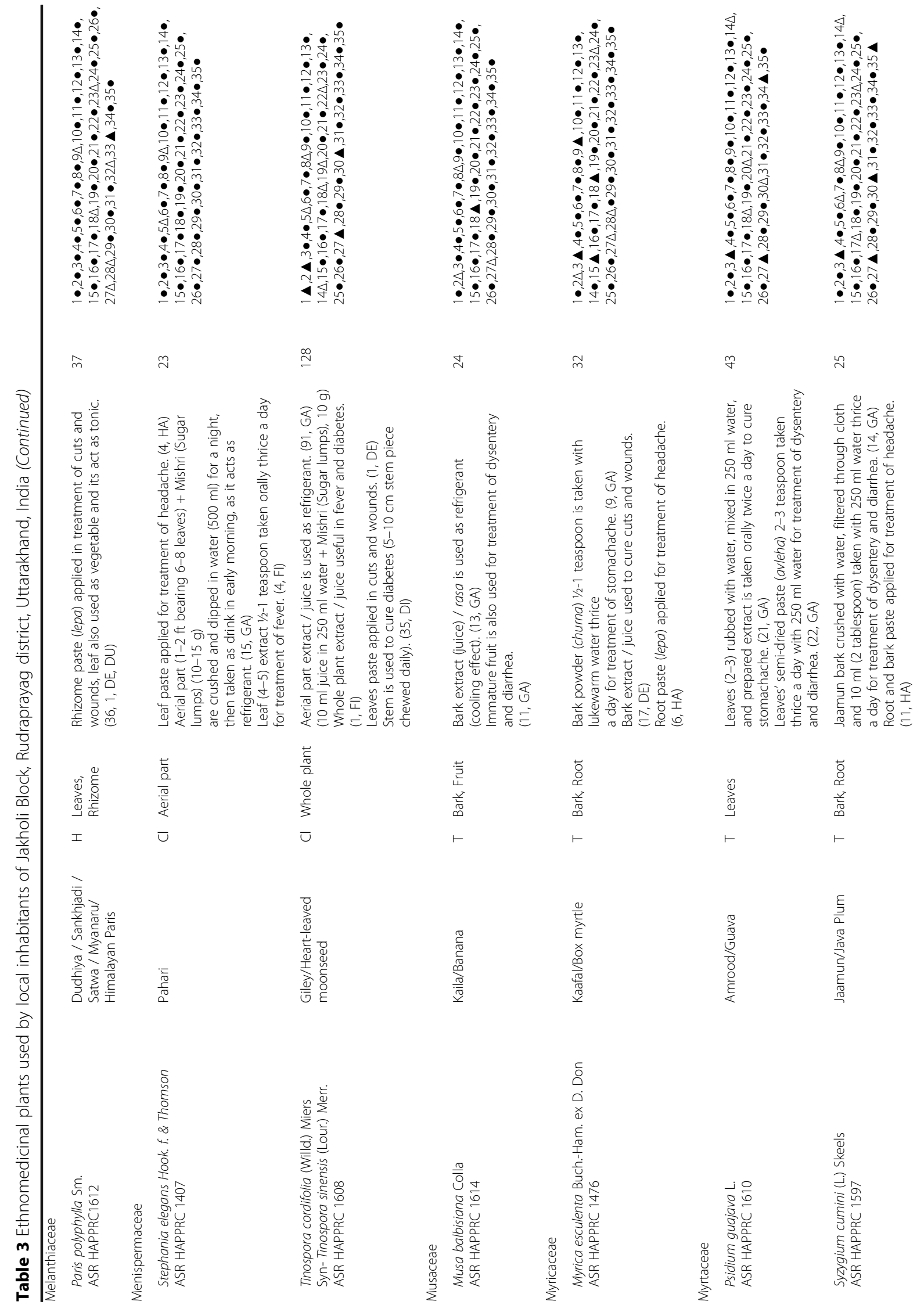




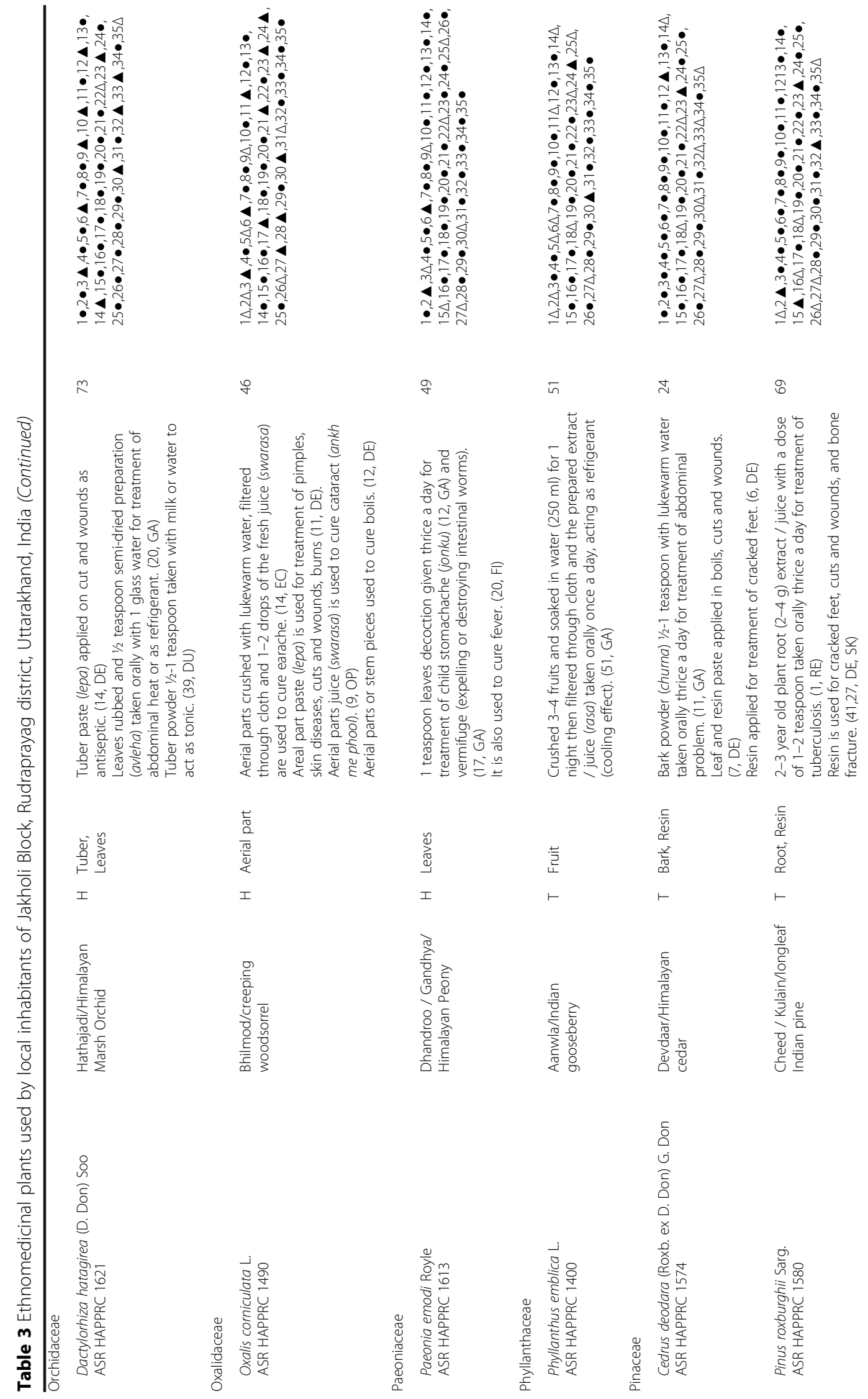




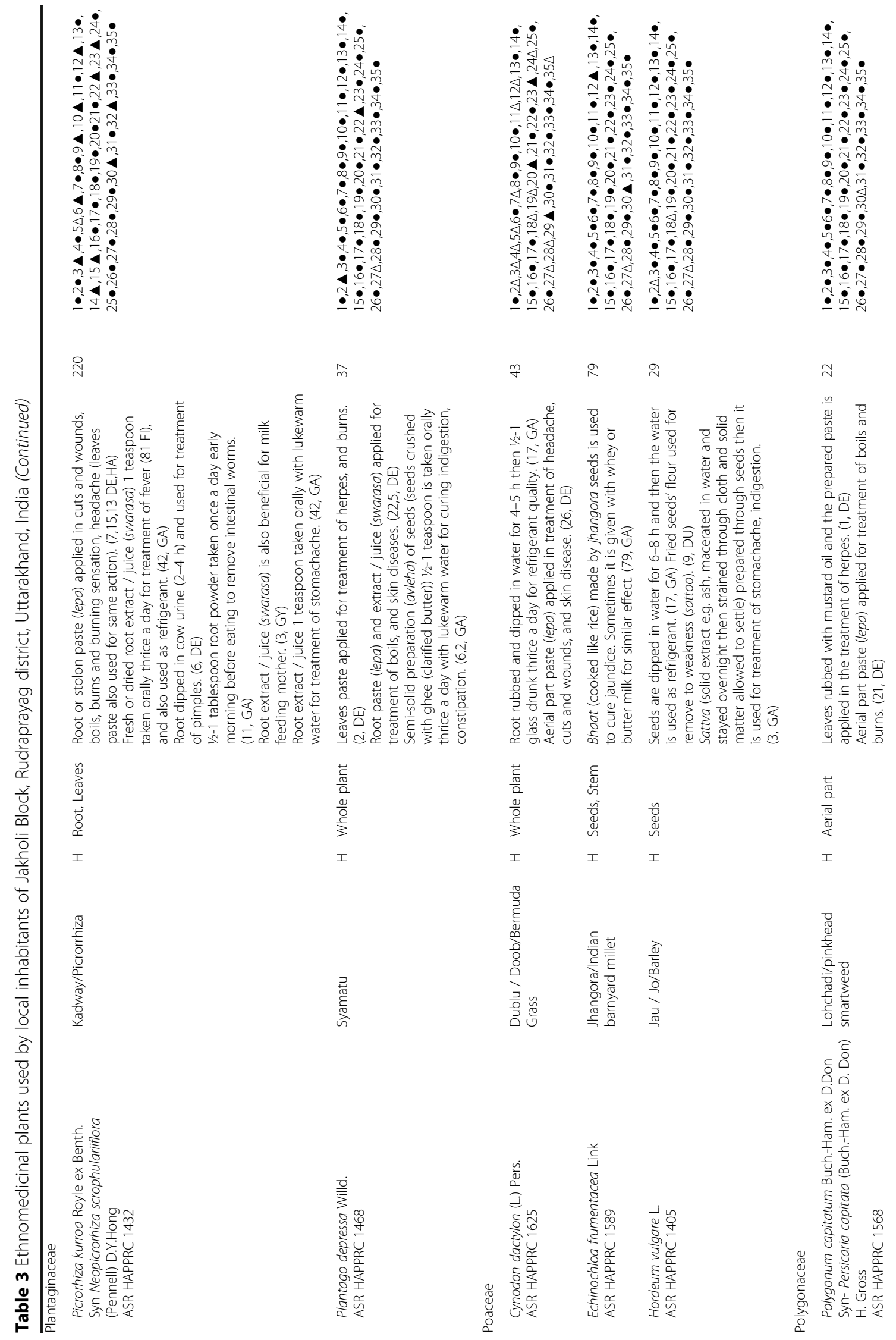




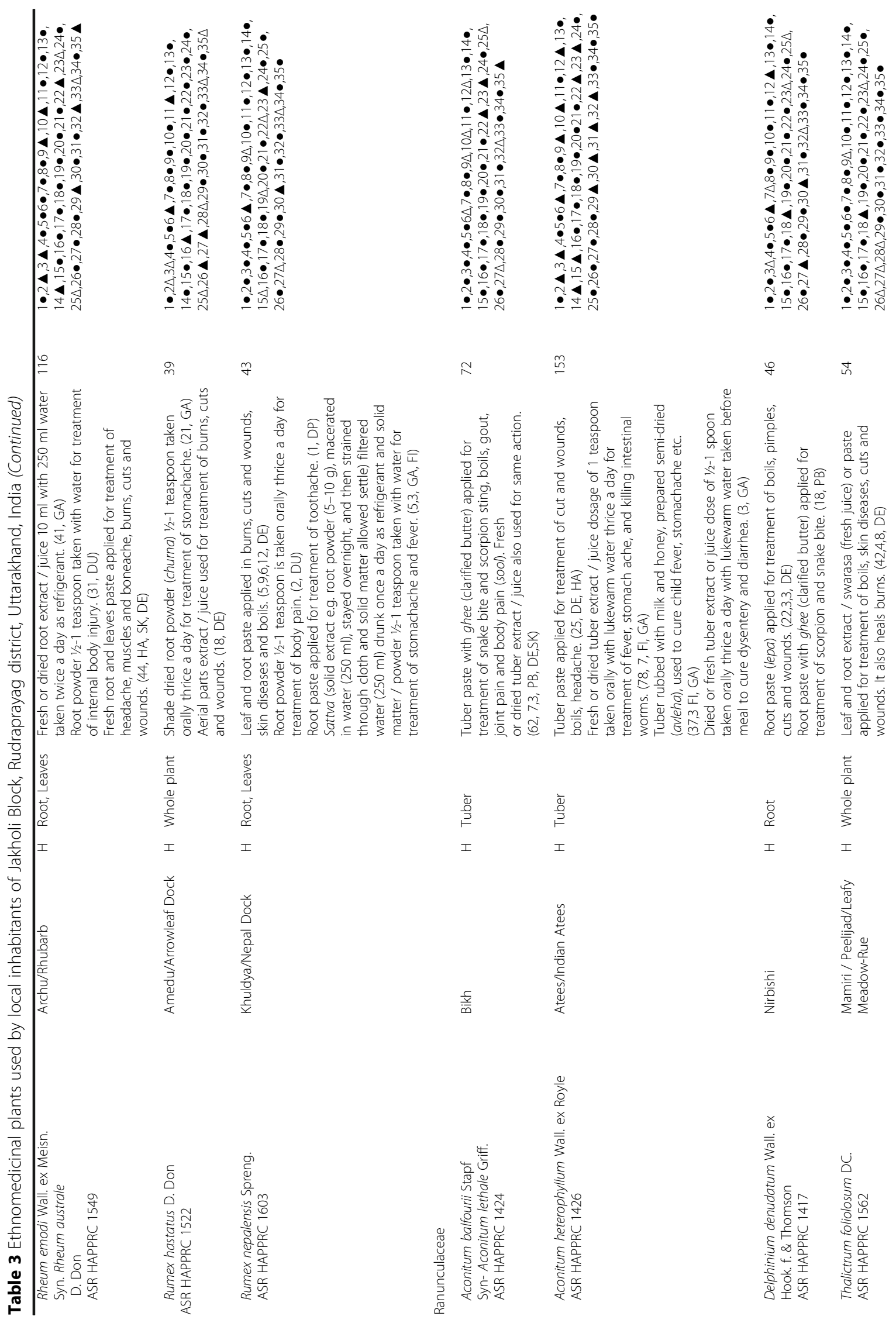




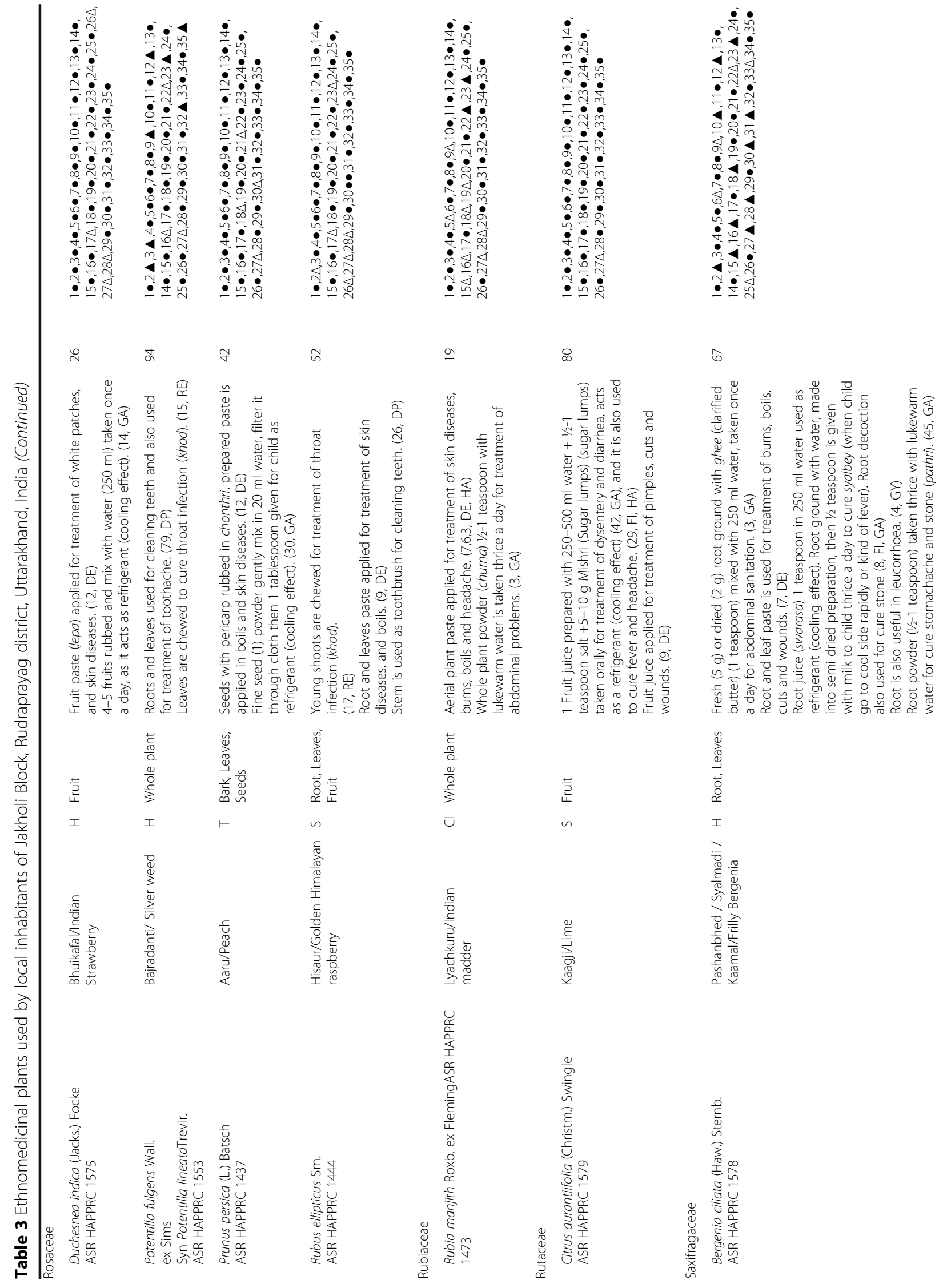


Singh et al. Journal of Ethnobiology and Ethnomedicine (2017) 13:49

Page 16 of 29

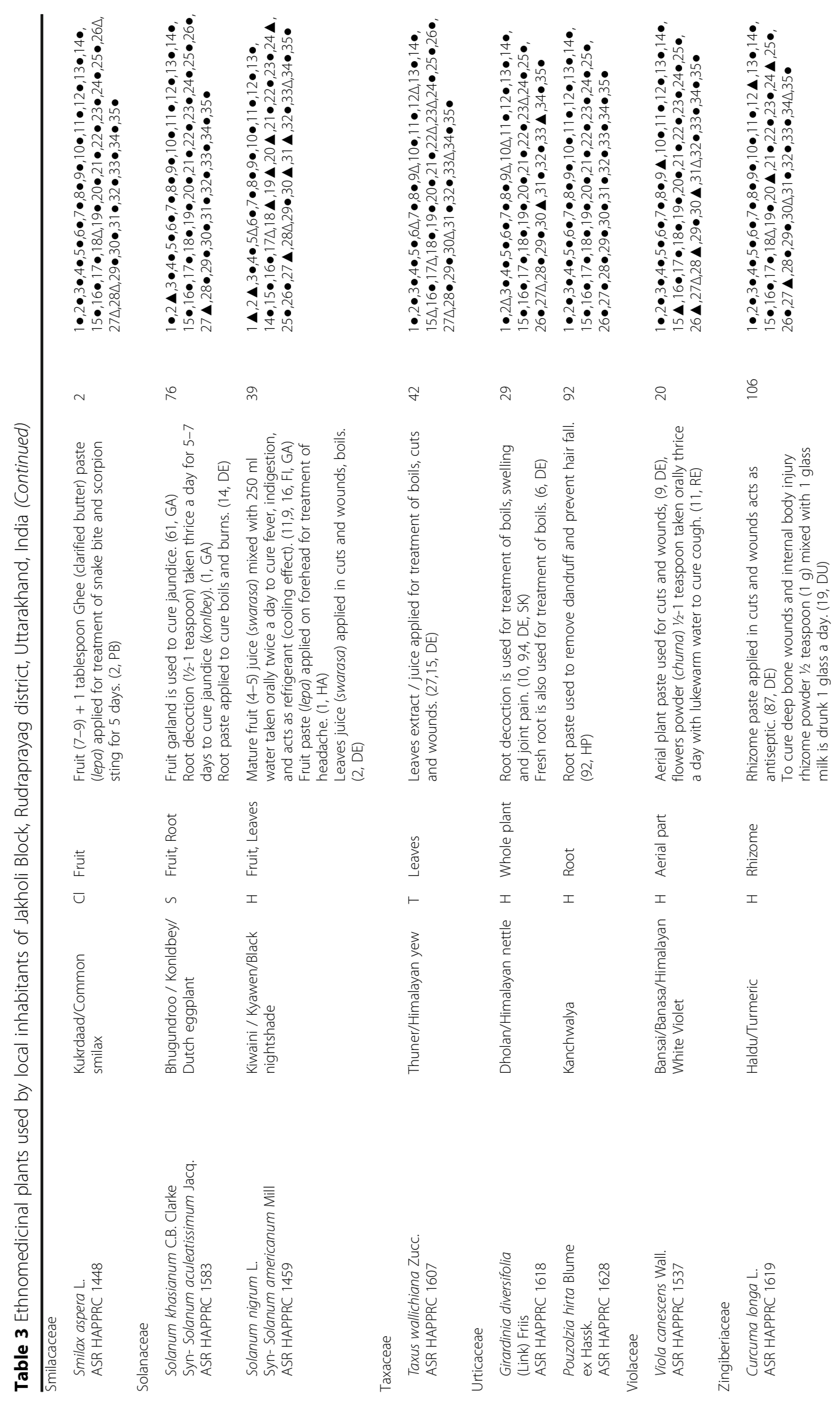




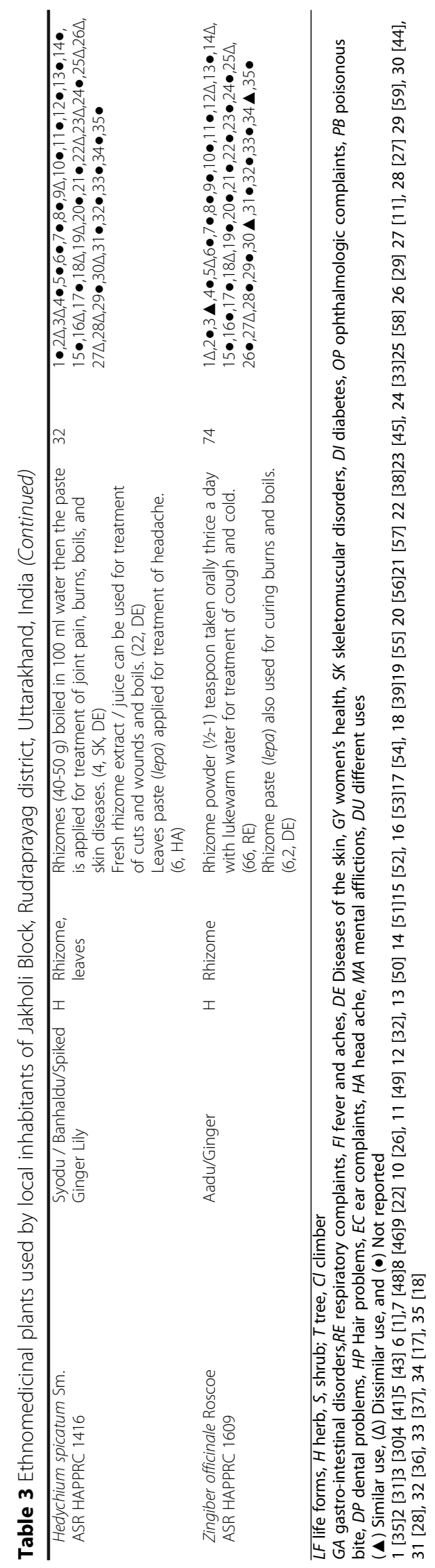




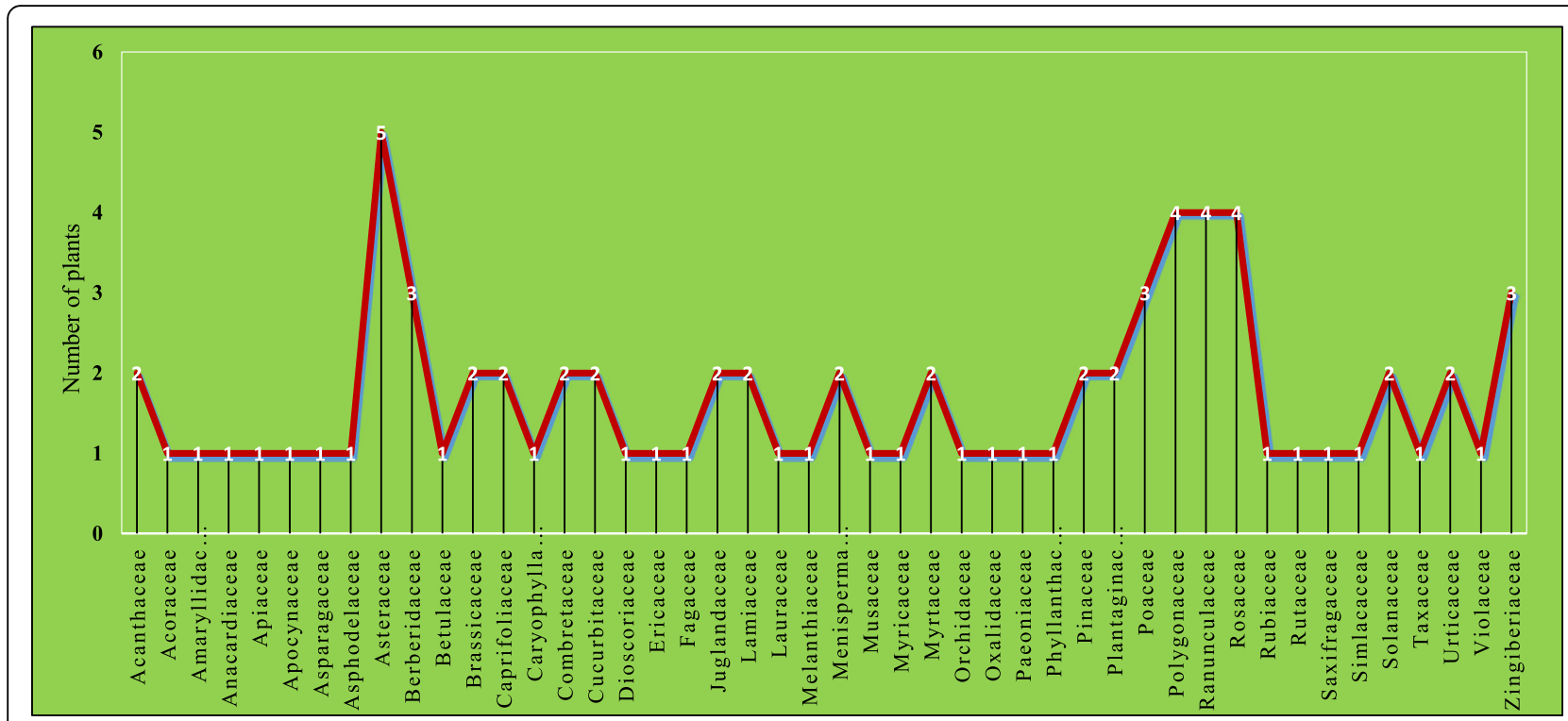

Fig. 3 Number of medicinal plants in different families

inhabitants for drug preparation are: Chhonthri (made of stone in the shape of plate $10-12 \mathrm{~mm}$ thick and with a diameter of $15-20 \mathrm{~cm}$ and a weigh of about $0.5-1.0 \mathrm{~kg}$ (Fig. 2d), Kharad (also made of stone $20 \mathrm{~cm} \times 45 \mathrm{~cm}$, $3-5 \mathrm{~kg}$ weight), Silbatta/Silotu (made of stone $30 \times 60$ $\mathrm{cm}, 15-25 \mathrm{~kg}$ weight) (Fig. 2d), Imaamdasta (made of stone or readymade china ceramic, $3-5 \mathrm{~kg}$ weigh).

\section{Informant consensus factor (ICF)}

The consensus of participants on medicinal plants reported for treating different ailments was quantitatively analyzed. To develop this consensus, all treated diseases are grouped into 15 categories. ICF value ranged from $0.91-0.99$, inferring the high consensus value among participants, however the $100 \%$ consensus was not reported. The highest ICF value (0.99) was for hair problems (HP), followed by Ophtalmologic complaints (OP) Mental afflictions (MA) 0.98 (Table 4). Our result repudiated the earlier findings and found the highest ICF for HP and OP. It may be due to low availability of market based nutraceuticals and OP was attributed by the poor sanitation, frequent injuries made by scrubs, wind, insects and poisonous flowers/pollens. Low consumption of water, high intensity light, hard work might be one of the important factors causing MA. High ICF values from adjoining areas were recorded for haematological disorder (1.00) [26], Liver disorder (0.56) [27], Malaria, Measles, Giddiness (each 1.00) [28].

\section{Ailments and useful species}

A total of 4967 therapeutic URs were documented for 15 different ailments categories and the most (1468 reports) were related to diseases of skin (DE) (29.55\%). This account was accorded to the findings of Saha et al. [29] confirming that dermatology is the most represented therapeutic category in India, followed by Gastrointestinal disorder (GA) (25.89\%) (Table 4). Women's health (GY) cited less UR (0.70\%).

A total of 1286 URs from 39 medicinal plants were reported to treat gastrointestinal ailments (GA) (killing intestinal worms, dysentery and diarrhoea, refrigerant, stomach ache, abdominal sanitation, indigestion,

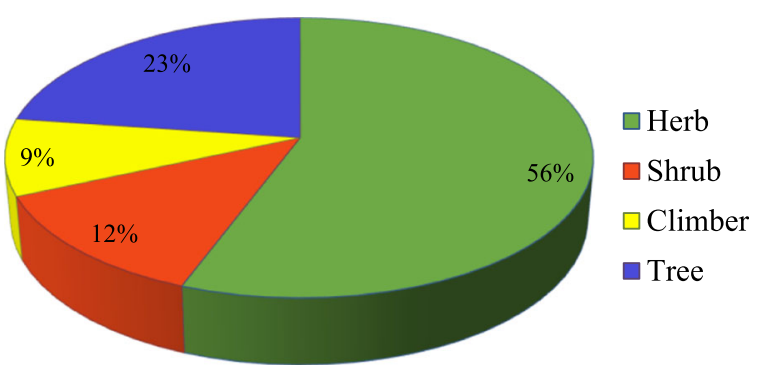

Fig. 4 Proportion of different life forms used as medicinal plants in Jakholi 


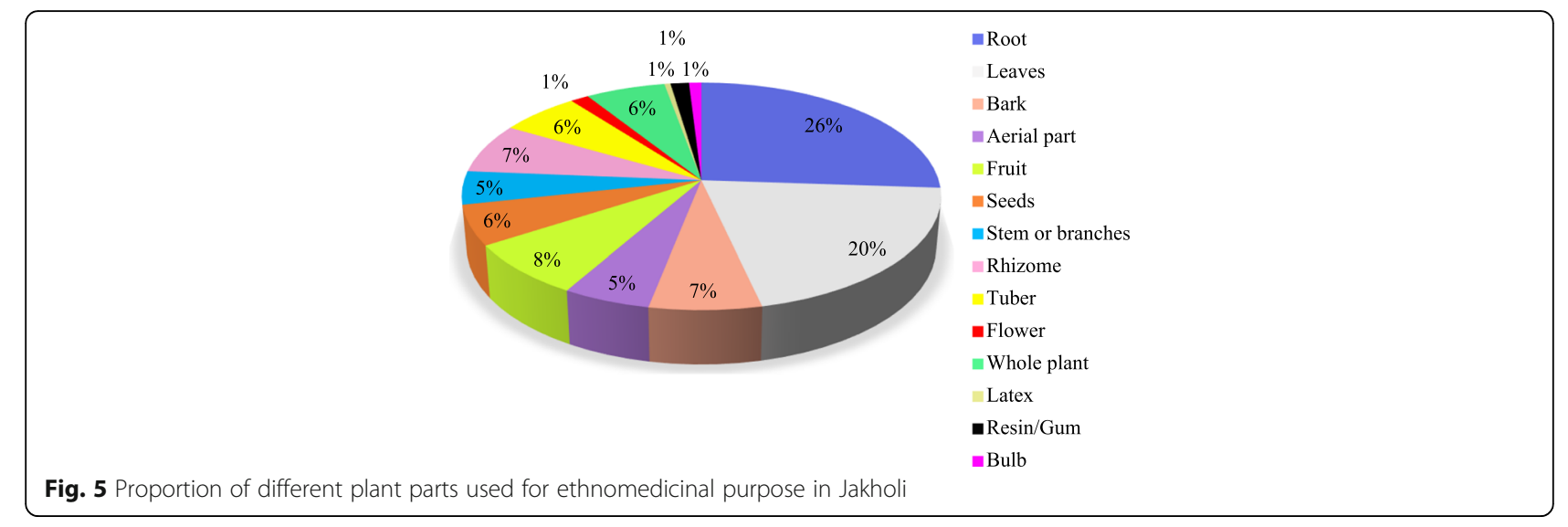

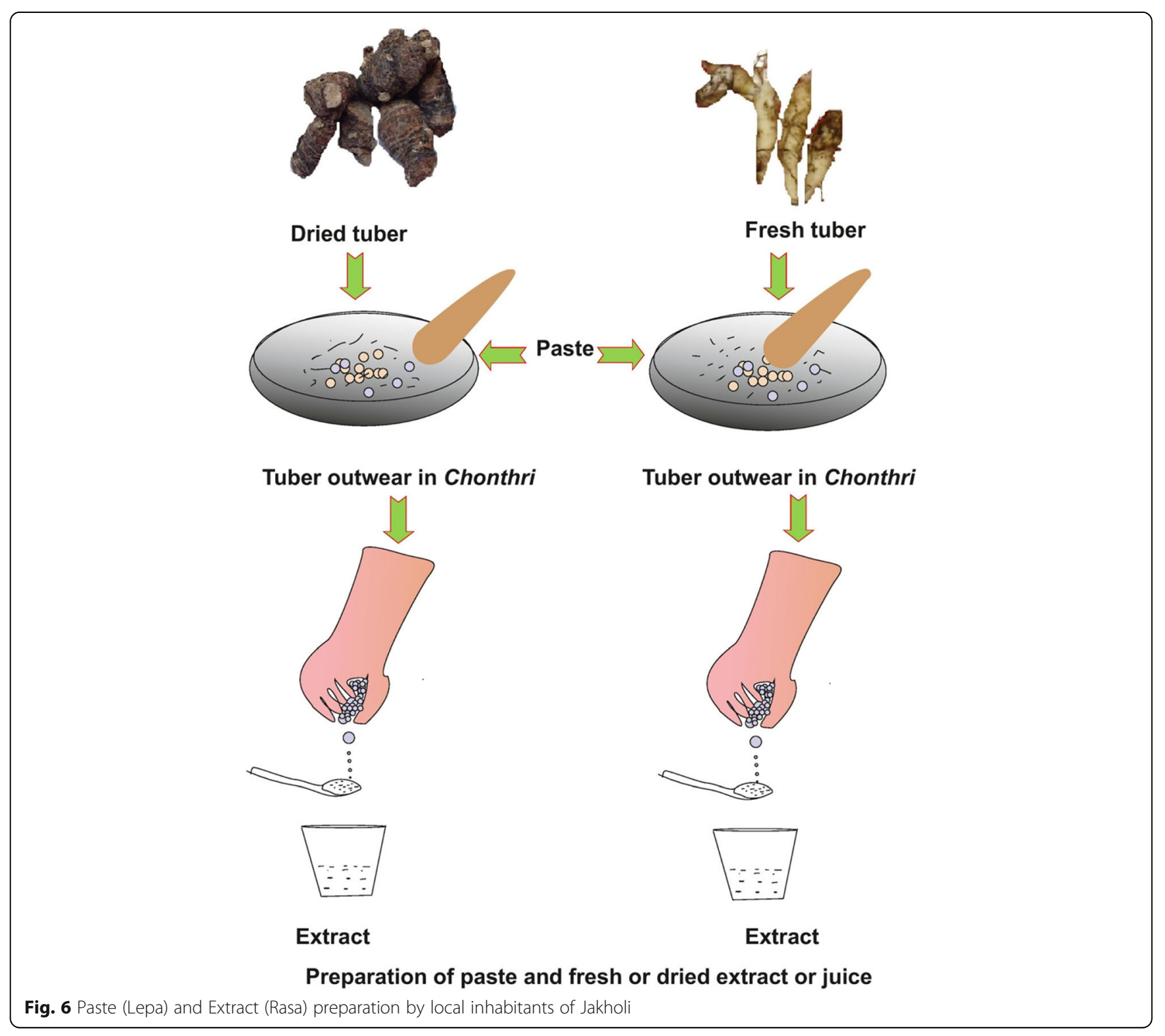




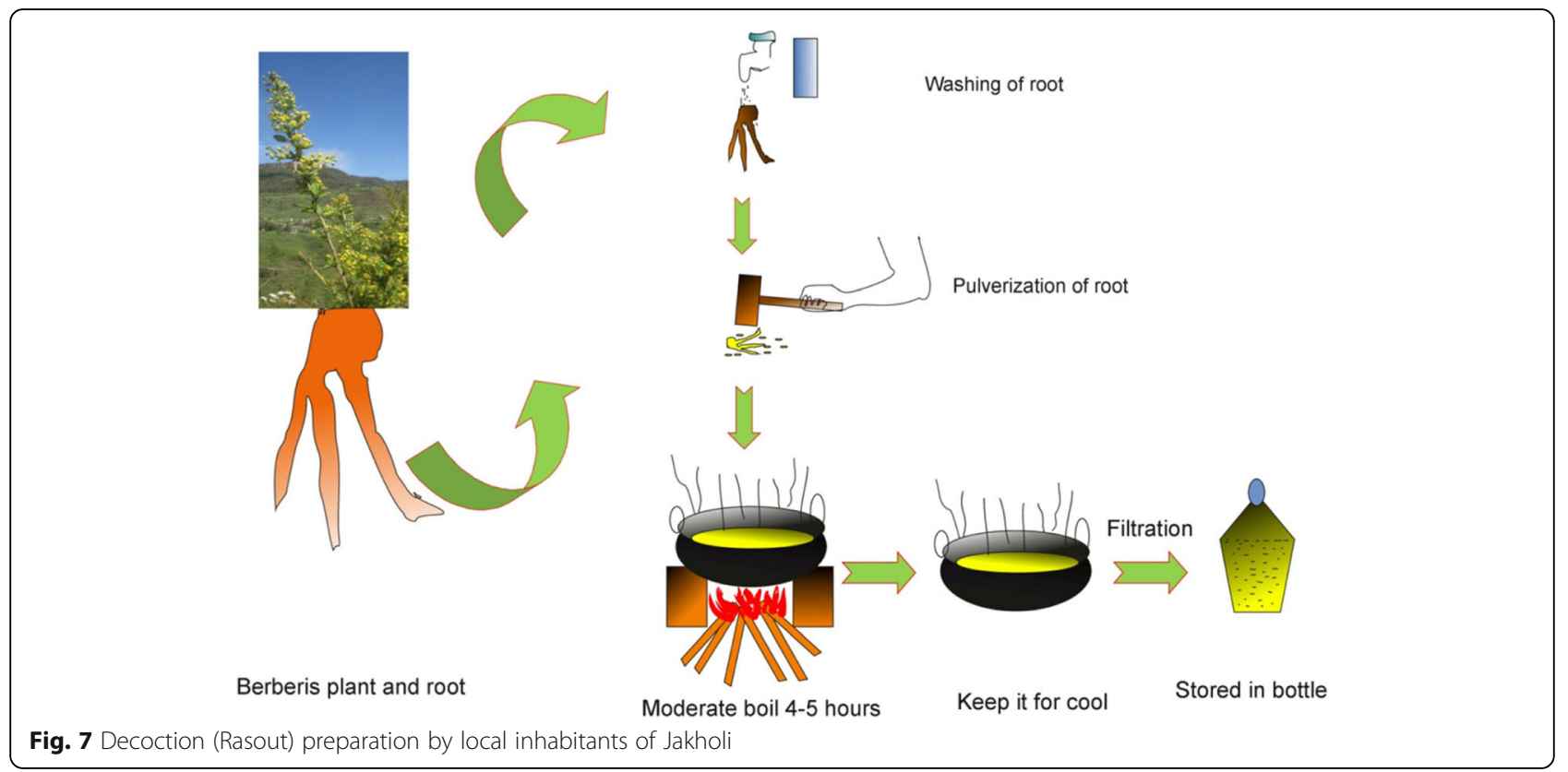

carminative, and constipation) with ICF value 0.97. Tinospora cordifolia was highly cited for refrigerant in this ailments category with 91 URs it is commonly known as Giley. Echinochloa frumentacea was frequently cited for jaundice with 79 URs. Megacarpaea polyandra used as refrigerant with 56 URs, however Semwal et al. [30] and Singh and Rawat [22] reported it for fever, asthma, stomach ache and dysentery. Bergenia ciliata commonly known as Pashanbhed / Syalmadi / Kaamalhighly was cited for curing gallstone with 53 URs, similar account was made by Uniyal and Shiva [31].

Total 219 URs and 10 taxa were cited for respiratory complaints (RE) categories and ICF value is 0.95 . Cough and cold, tuberculosis and throat infection use reports were common in RE due to cold, fluctuation in temperature, and high smoking. Zingiber officinale commonly known $A a d u$, was highly cited for cough and cold with 66 UR as reported by Semwal et al. [30] for cough and cold with honey. Alien and invasive plant
Eupatorium adenophora was used for cough and cold with18 URs. A total of 437 URs and 15 taxa were mentioned for fever and aches complaints (FI) categories with ICF value (0.96). Picrorhiza kurroa and Aconitum heterophyllum highly cited for fever and headaches with 81 and 78 URs, substantiate the findings from Garhwal by Uniyal and Shiva [31], Semwal et al. [30], Malik et al. [1], Singh and Rawat [22]., Highest number of URs (1468) from 53 species for skin diseases (DE) with ICF value (0.96) was noted for treatment of cuts and wounds, boils, burnt, pimples, white patches and herpes. Cut and wounds and boils are commonly occurred in hilly areas due to narrow trails and intensive thorny shrubs, tiresome work with sharp tools and implements, etc. Eupatorium adenophora was highly cited for cut and wounds with 108 URs followed by Curcuma longa with 87 URs, consistent with the findings of Phondani et al. [32], Tewari et al. [33] and Gaur [11]. Women's health problems like galactogogue and leucorrhoea were

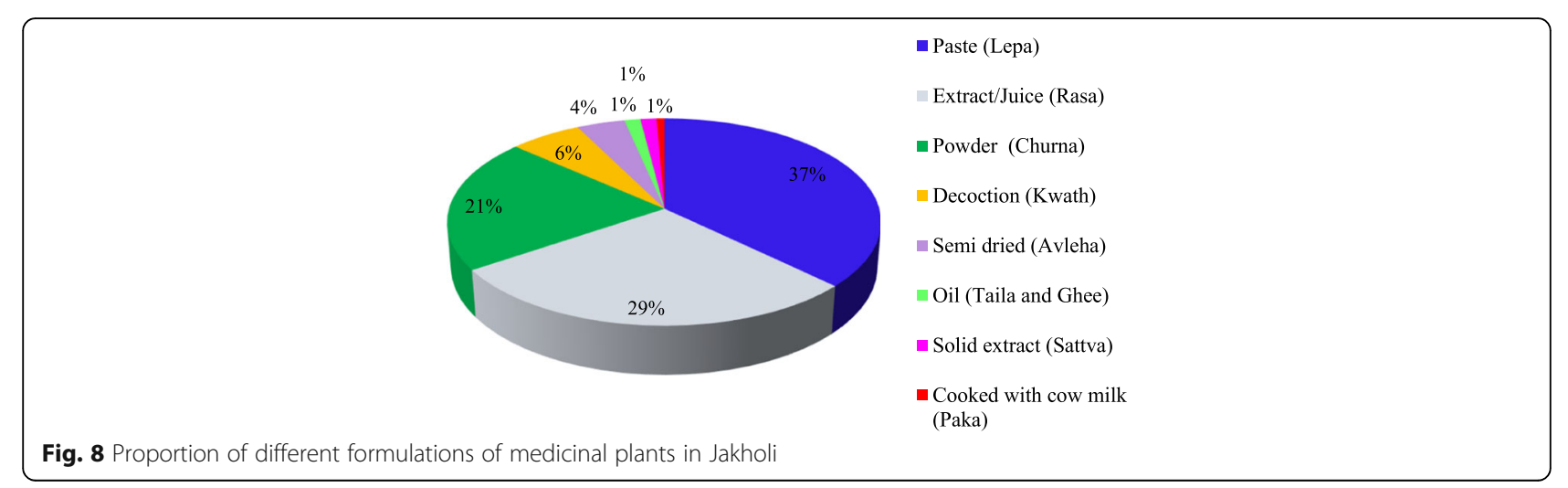


Table 4 Informant consensus factor for ailment categories

\begin{tabular}{llllll}
\hline $\begin{array}{l}\text { Ailment categories } \\
\text { (group of illness) }\end{array}$ & $\begin{array}{l}\text { Number of use } \\
\text { reports (Nur) }\end{array}$ & $\begin{array}{l}\text { \% of use } \\
\text { reports }\end{array}$ & $\begin{array}{l}\text { Number of } \\
\text { taxa (Nt) }\end{array}$ & $\begin{array}{l}\text { \% of } \\
\text { taxa }\end{array}$ & $\begin{array}{l}\text { Informant consensus } \\
\text { factor (ICF) }\end{array}$ \\
\hline Women's health (GY) & 35 & 0.70 & 4 & 5.12 & 0.91 \\
Head ache (HA) & 199 & 4.00 & 14 & 17.94 & 0.93 \\
Respiratory complaints (RE) & 219 & 4.40 & 10 & 12.82 & 0.95 \\
Diabetes (DI) & 49 & 0.98 & 3 & 3.84 & 0.95 \\
Diseases of the skin (DE) & 1468 & 29.55 & 53 & 67.94 & 0.96 \\
Skeletomuscular disorders (SK) & 128 & 2.57 & 6 & 7.69 & 0.96 \\
Ear complaints (EC) & 104 & 2.09 & 5 & 6.41 & 0.96 \\
Poisonous bite (PB) & 91 & 1.83 & 4 & 5.12 & 0.96 \\
Gastrointestinal disorders (GA) & 1286 & 25.89 & 39 & 50 & 0.97 \\
Fever and Aches (FI) & 437 & 8.79 & 15 & 19.23 & 0.96 \\
Dental problems (DP) & 275 & 5.53 & 7 & 8.97 & 0.97 \\
Mental afflictions (MA) & 71 & 1.42 & 2 & 2.56 & 0.98 \\
Ophthalmologic complaints (OP) & 252 & 5.07 & 4 & 5.12 & 0.98 \\
Hair problems (HP) & 104 & 2.09 & 2 & 2.56 & 0.99 \\
Different uses (DU) & 249 & 5.01 & 10 & 12.82 \\
TOTAL & 4967 & & & 0.95 \\
\hline
\end{tabular}

treated by Asparagus adscendens, Picrorhiza kurroa, Bergenia ciliata and Quercus leucotrichophora. This result is consistent with the findings of Azad and Bhat [34]. Rheum emodii was highly cited for bone ache with 44 URs as noted by Semwal et al. [30]. Tinospora cordifolia was highly cited for diabetes with URs 35 followed by Berberis chitria and Berberis lyceum with 7 URs for treatment of diabetes. However, Chandra et al. reported Berberis lyceum for ophthalmic complaints [35], Uniyal and Shiva for antiseptic, blood purifier, conjunctivitis [31]. Ophthalmologic complaints (OP) was the second highest ICF value recorder. Berberis chitria commonly known Totar/Totru root decoction commonly called Rasout 1-2 drops was used to treat eye infection with 110 URs followed by 101 URs of Berberis lyceum for eye complaints, similar observations were made in Himalayan areas [1, 28, 36, 37]. Centella asiatica was also beneficial for eye sight with 40 URs. The use of plants or poisonous bite $(\mathrm{PB})$ was moderately consented and only 91 URs from 4 taxa were cited for poisonous bite (PB) complaints with ICF value 0.96. Aconitum balfourii was used for Snake bite and Scorpion sting with 62 URs as Rana et al. [38] recorded. Juglans regia was cited for cleaning teeth and for treatment of pyorrhoea with 89 URs similar to Uniyal and Shiva [31], Semwal et al. [30], Malik et al. [1] Highest consensus was reported for treatment of hair problems. A total of 104 URs from only 2 species Pouzolzia hirta and Brassica juncea were cited for hair problems. Pouzolzia hirta commonly known as Kanchwalya tuberous root paste is used as shampoo and highly cited for to remove dandruff and prevent hair fall.
Brassica juncea was also cited for ear problems with 42 URs similar to Semwal et al. [30] and Kumari et al. [39]. Rheum emodii root and leaf paste was cited for headache, consistent with the observation of Rehman et al. [40]. Species Nardostachys jatamansi and Valeriana jatamansi were cited for mental disorder and insomnia, as evidenced by Semwal et al. [30], Sharma et al. [41] and Shah et al. [29]. In sense of plants used, the highest number was observed for DE categories (67.94\%) followed by Gastro- intestinal ailments (GA) (50\%). It has been affirmed that the local people are interested to use herbal therapies predominantly for the management of dermatological and gastro-intestinal ailments. The reported plants having high citations against above mentioned diseases should be further evaluated and analyze through pharmaceutical and biological properties [24, 42].

\section{Threatened species}

Of the plants recorded for ethnomedicinal, 29 plant species are prioritized for conservation (Table 5). These threatened species are available in restricted pocket of Garhwal Himalaya, and locally threatened due to premature and over-exploitations (Fig. 9). Eleven local highly threatened species were cited by local inhabitants of Jakholi and overexploitation as principle cause of threat cited by local inhabitants for all local threatened species. Alpine species are highly threatened, which may be influence by other cause viz. long vegetative phase and less propagation, decreasing natural water resources and global warming. (Table 6/ Fig. 10). 
Singh et al. Journal of Ethnobiology and Ethnomedicine (2017) 13:49

Page 22 of 29

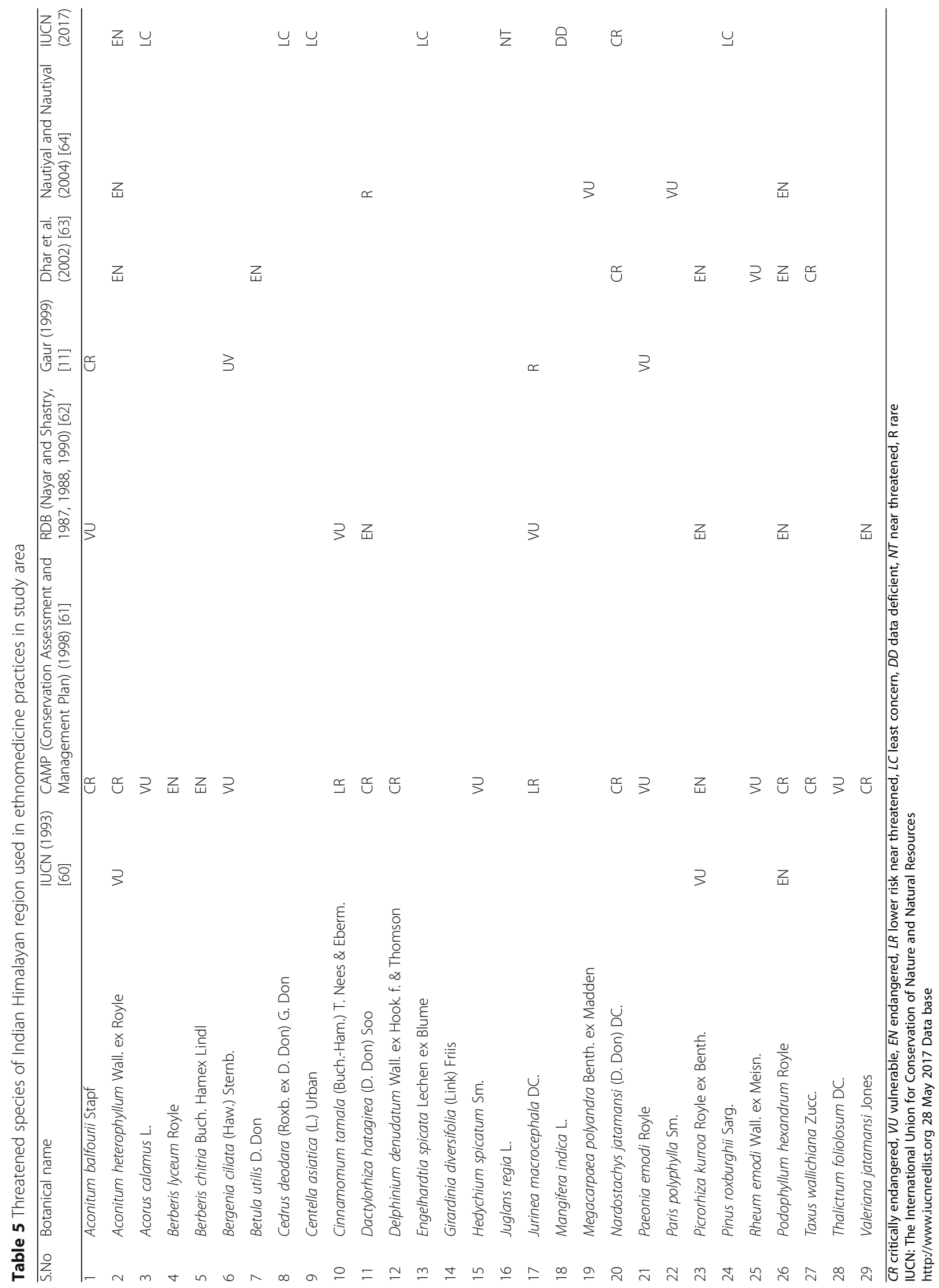




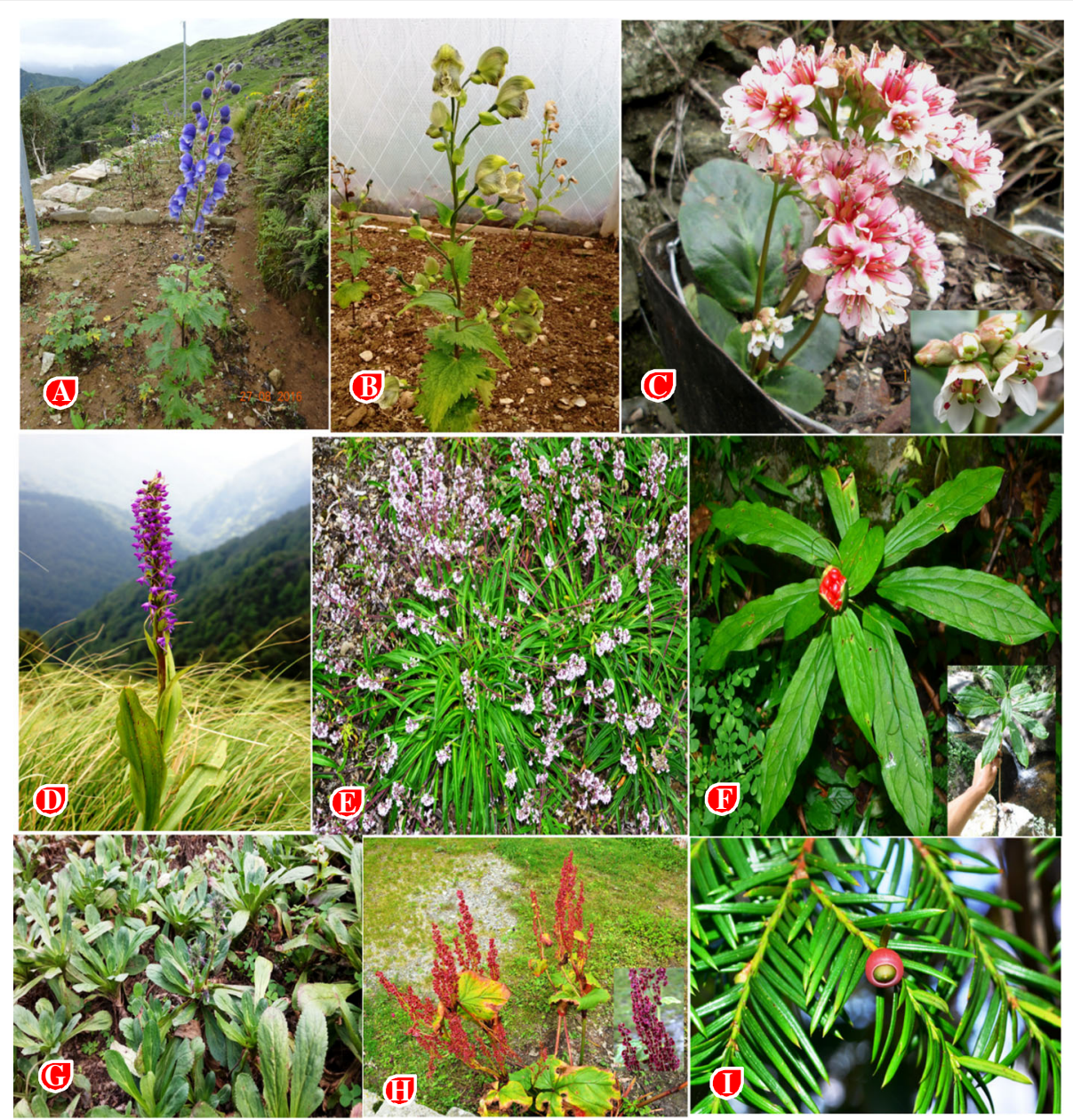

Fig. 9 Threatened species in study area a Aconitum balfaourii b Aconitum heterophyllum c Bergenia ciliata d Dactylorhiza hatagirea e Nardostachys jatamansi $\mathbf{f}$ Paris polyphylla $\mathbf{g}$ Picrorhiza kurroa $\mathbf{h}$ Rheum emodi i Taxus wallichiana

\section{Reliability and comparison}

Cultural practices of particular region directly affected by floral and faunal wealth and variance among them indicate importance of particular region. For similarity, dissimilarity and new use reports uses of plants documented in our study were compared to 35 published ethno-botanical studies from Indian Himalaya as well as neighbouring countries (Table 7). In the present study, the similarity of uses as compared to other studies ranged from 0 to $30 \%$ while dissimilar uses varied widely from 42.5 [43] to $1.58 \%$ [44]. JI range between $2.86-$ 56.66 and Sorensen's index 5.56-72.34 were obtain. The highest degree of similarity was found with studies conducted by Kala [45] with JI 55.66 and SI 72.34 and Uniyal and Siva [31] with JI 49.35, SI 66.08. The lowest indices of similarity are found with studies of Samant et al. [36] and Ghildiyal et al. [46] (JI 2.86 and 3, SI 5.56 and 5.83). Comparison of medicinal flora and uses within district and block only two reports were found which have more than $30 \mathrm{JI}$ and 50\% SI similarity (49.35
JI, 66.08 SI Uniyal and Siva [31] and 39.68JI, 56.81 SI Semwal et al.) [30]. It appears that the distance between study area and neighbouring region is responsible for any change in JI [24]. The highest similarity index was not surprisingly observed with the nearest areas, which had high similarity indices with respect to plant use and modes of applications.

This occurrence may be due to the sharing of a similar flora and the cross-cultural exchange of medicinal plant knowledge in past and present. It also indicates similar ethno-genesis of people in comparative areas [47]. Besides, low similarity indices may be likely due to minimal cultural exchange between the mountains region as they are disconnected through mountain ranges and other cultural variations [24]. However, region to region similar medicinal flora are used in various way. Low similarity with the other report may be due to different topography and climatic condition and medicinal flora or it could be a sign of loss of cultural practices. 
Table 6 Consensus and observation for local threatened medicinal plants and their causes by local inhabitants of Jakholi

\begin{tabular}{|c|c|c|c|c|c|c|}
\hline Botanical name & $\begin{array}{l}\text { Availability / } \\
\text { Citation } \\
\text { ECitation }\end{array}$ & $\begin{array}{l}\text { Restricted } \\
\text { pockets } \\
\text { ¿Citation }\end{array}$ & $\begin{array}{l}\text { long vegetative phase/ } \\
\text { less propagation } \\
\Sigma \text { Citation }\end{array}$ & $\begin{array}{l}\text { Global worming /decreasing } \\
\text { natural water resources } \\
\Sigma \text { Citation }\end{array}$ & $\begin{array}{l}\text { Unfair trade/ } \\
\text { Overexploitation } \\
\Sigma \text { Citation }\end{array}$ & $\begin{array}{l}\text { No idea } \\
\Sigma \text { Citation }\end{array}$ \\
\hline Aconitum balfourii Stapf & $\mathrm{R} / 98$ & 113 & 42 & 14 & 109 & 15 \\
\hline Aconitum heterophyllum Wall. ex Royle & VR/183 & 106 & 78 & 26 & 193 & 4 \\
\hline Acorus calamus L. & S/93 & 10 & 5 & 32 & 168 & 12 \\
\hline Dactylorhiza hatagirea (D. Don) Soo & $R / 109$ & 165 & 69 & 19 & 143 & 7 \\
\hline $\begin{array}{l}\text { Megacarpaea polyandra Benth. ex } \\
\text { Madden }\end{array}$ & $R / 103$ & 142 & 49 & 25 & 91 & 12 \\
\hline Nardostachys jatamansi (D. Don) DC. & VR/176 & 125 & 65 & 32 & 125 & 11 \\
\hline Paris polyphylla Sm. & S/91 & 45 & 33 & 23 & 102 & 9 \\
\hline Picrorhiza kurroa Royle ex Benth. & $V R / 174$ & 198 & 64 & 21 & 201 & 9 \\
\hline Rheum emodi Wall. ex Meisn. D. Don & $R / 125$ & 164 & 15 & 29 & 95 & 6 \\
\hline Podophyllum hexandrum Royle & $R / 81$ & 112 & 21 & 13 & 61 & 14 \\
\hline Taxus wallichiana Zucc. & $R / 76$ & 67 & 46 & 11 & 129 & 5 \\
\hline
\end{tabular}

$S$ scattered, $R$ rare, $V R$ very rare $(N=220)$

\section{Novelty and future prospects}

The present study was compared with the previous studies related to analysis of ethnomedicinal plants and their uses in Himalaya. This comparative analysis in the ethnomedicinal point of view found the following new reports as Calotropis gigantea for joint pain, swelling (37 UR) and skin diseases (2 UR); Citrus aurantiifolia for dysentery, diarrhea and as refrigerant with 42 UR; Cucumis sativus for fever with 65 UR; Dioscorea bulbifera for fever (17 UR) and boils (16 UR); Drymaria cordata for herpes (6 UR) fever and headache (13 UR); Duchesnea indica for Skin diseases (12 UR) and as refrigerant (14
UR); Engelhardtia spicata for cleansing teeth (37) and treatments of boils, cut and wounds (50 UR); Hedychium spicatum for skin diseases and boils, cut and wounds, joint pain (26 UR); Hordeum vulgare for weakness (9 UR) as refrigerant (17 UR); Mangifera indica used for stomachache (12 UR), dysentery and diarrhea (19 UR) (especially for child); Prunus persica used for boils, skin diseases (12 UR) and as refrigerant (30 UR); Polygonum capitatum for boils, burnt (21) herpes (1); Pouzolzia hirta to remove dandruff and prevent hair fall (92 UR); Rubus ellipticus for throat infection (17 UR), boils and skin diseases (9 UR) and cleaning teeth (26 UR); Stephania

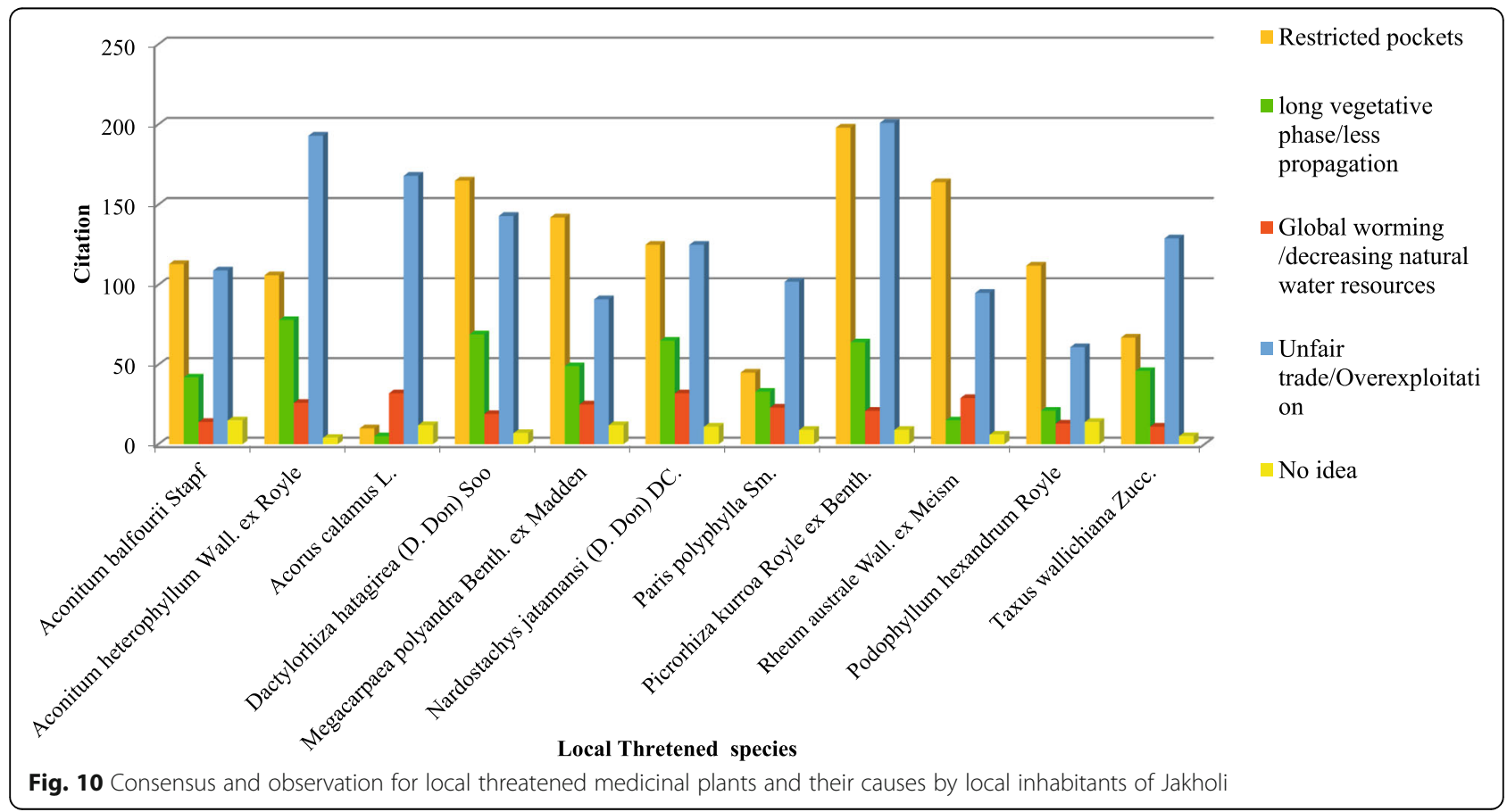




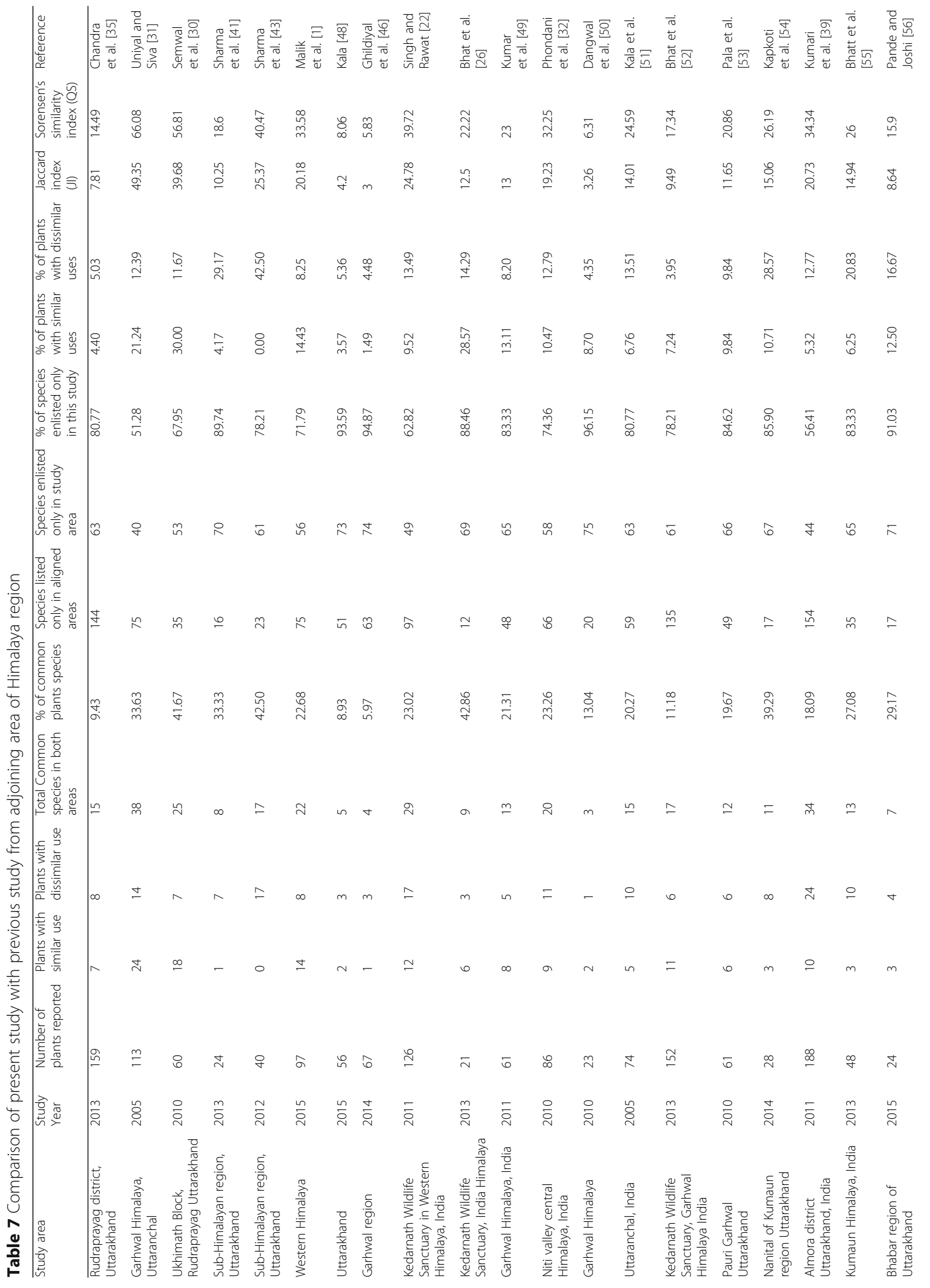




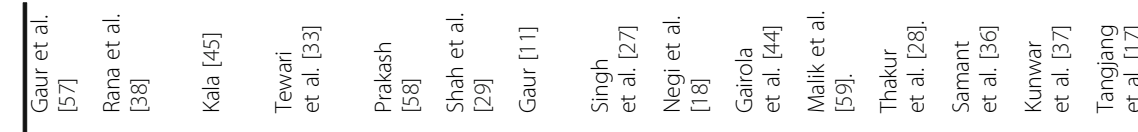

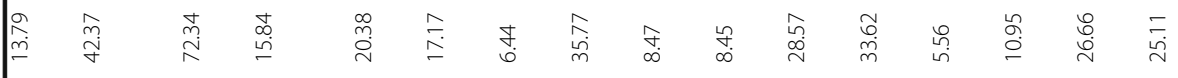

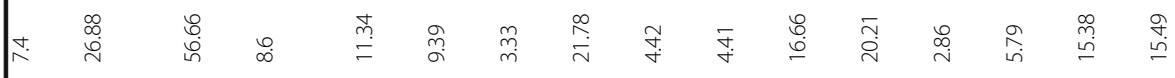

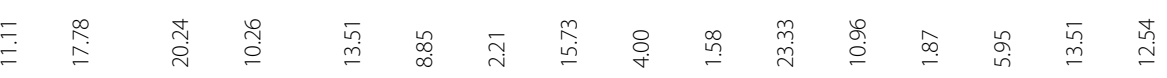
م্লm

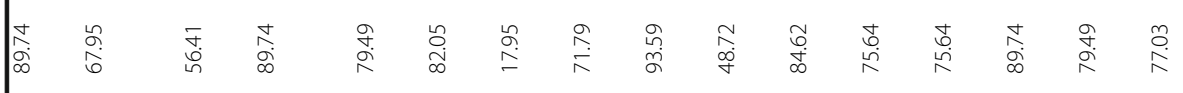

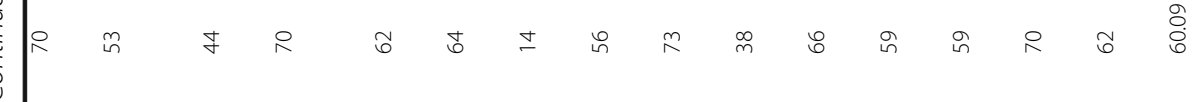

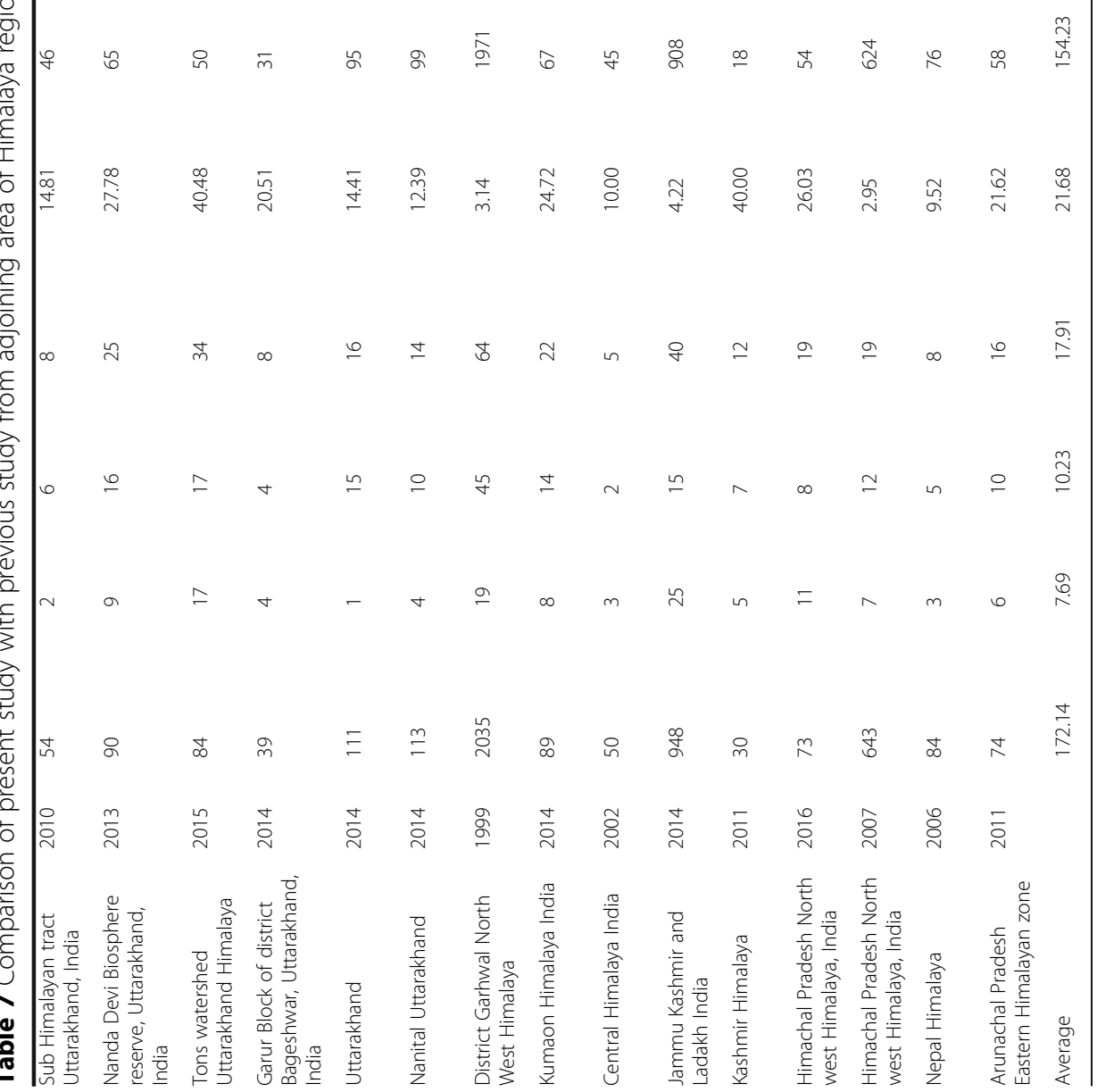




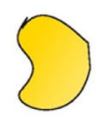

Mango ripen fruit

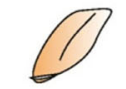

Seed

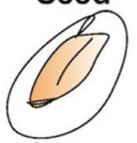

Seed covered with kneaded dough

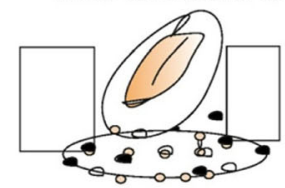

Ember and ash

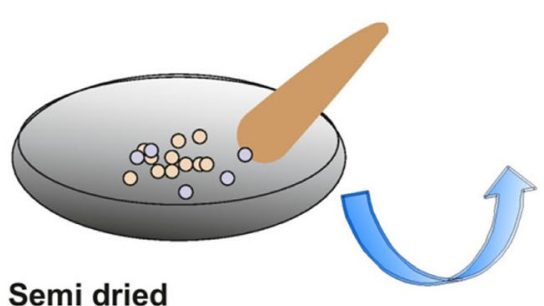

Semi dried

powder of kernel pulverise on Chonthri
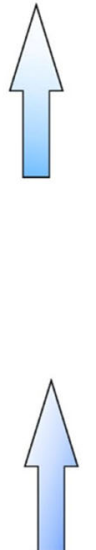

\section{r}

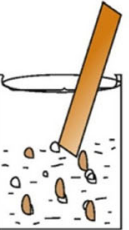

Gently mix with water

Filter
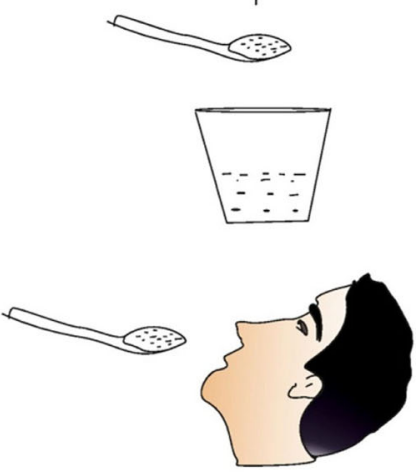

Administrated

Fig. 11 Preparation of seed extract by local inhabitants of Jakholi

elegans for headache (4 UR), acts as refrigerant (4 UR), fever (4 UR); Smilax aspera for snake-bite and scorpionsting (2 UR), Taxus wallichiana for boils (27 UR), cuts and wounds (15 UR) and Trichosanthes tricuspidata for fever (65 UR) (Table 3) were newly reported ethnomedicinal uses.

Some of plant species such as Aconitum heterophyllum, Eupatorium adenophora, Echinochloa frumentacea, Engelhardtia spicata, Megacarpaea polyandra, Picrorhiza kurroa, Polygonum capitatum, Plantago depressa, Potentilla fulgens, Quercus leucotrichophora, Senecio nudicaulis were frequently used in Jakholi but their detailed bioactive constituents and pharmacological activity are yet unknown, revealing a good candidature for pharmacological and therapeutic values and extraction of novel bioactive constituents (Fig. 11).

\section{Conclusions}

Present paper is the first attempt of survey in Jakholi Block, Uttarakhand, India. Asteraceae, Polygonaceae, Ranunculaceae and Rosaceae were the most used families and root were the most commonly used plant parts in the area. Aconitum heterophyllum, Megacarpaea polyandra, Picrorhiza kurroa and Rheum emodii are well known medicinal plant species, contributing important role in the local health care system of Jakholi area. Documentation of local medicinal knowledge is also essential due to outmigration of the younger. Study of ethnomedicinal knowledge helps identify the important species of the region for pharmacological importance and ecological sustainability and it also aids conservation of traditional knowledge. Cataloguing useful plant species supports registration of indigenous knowledge, aiding national impetus of obeying implementation of convention of biological diversity and Nagoya protocol. Traditional knowledge is based on experience passed on from generation to generation and limited only to elderly (Bujurg) people and traditional healers. We came to the following considerations to be taken while doing ethnomedicinal studies in the Himalaya: (a) local people are quite conservative in sharing traditional knowledge about the Medicinal plants; (b) the young generation is not interested and knowledgeable about the ethnomedicinal plants and their uses; and (c) outmigration is a 
menace to the conservation of traditional ethnomedicinal knowledge. The present study showed that the medicinal plants are still very important for livelihood of local inhabitants of Jakholi and the Himalaya. Some medicinal plants are at the brisk of threatened due to their ecology, biology and human induced exploitations. To sum, documentation of useful plants and the knowledge of their utilization is immediate before being lost.

\section{Acknowledgements}

The authors are thankful to the local inhabitants, Shepherd, and local traditional healers (Vaidyas and Daai) of Jakholi Block for sharing their incredible knowledge with us. The first author is thankful to the Director, High Altitude Plant Physiology Research Centre, H.N.B. Garhwal University, Uttarakhand, India for facilities.

\section{Funding}

Not applicable.

\section{Availability of data and materials}

The raw data contain the names of all participants, and cannot be shared in this form.

\section{Author's contributions}

AS carried out a field survey and collected ethnomedicinal data, voucher samples and identified the plant material, analysed data and drafted the paper. MCN, RMK and RB revised the manuscript and give critical inputs. All authors have read the final manuscript and agreed to its submission.

\section{Ethics approval and consent to participate}

Before conducting interviews, prior informed consent was obtained from all participants. No further ethics approval was required.

\section{Consent for publication}

This manuscript does not contain any individual person's data and further consent for publication is not required.

\section{Competing interests}

The authors declare that they have no competing interests.

\section{Publisher's Note}

Springer Nature remains neutral with regard to jurisdictional claims in published maps and institutional affiliations.

\section{Author details}

${ }^{1}$ High Altitude Plant Physiology Research Centre, H.N.B. Garhwal University, Post Box: 14, Srinagar Garhwal, Uttarakhand 246174, India. Practical Solutions, Kathmandu, Nepal. ${ }^{3}$ William L. Brown Center, Missouri Botanical Garden, Missouri, USA.

Received: 16 February 2017 Accepted: 10 August 2017

Published online: 24 August 2017

\section{References}

1. Malik ZA, Bhat JA, Ballabha R, Bussmann RW, Bhatt BA. Ethnomedicinal plants traditionally used in health care practices by inhabitants of western Himalaya. J Ethnopharmacol. 2015:172:133-44.

2. Ballabha B, Chaurasia OP. Medicinal plants of cold desert Ladakh used in the treatment of stomach disorders. Indian J Tradit Knowl. 2009:8:185-90.

3. Kunwar RM, Baral K, Paudel P, Acharya RP, Thapa-Magar KB, Cameron M, Bussmann RW. Land use and socioeconomic change, medicinal plant selection and biodiversity resilience in far western Nepal. PLoS One. 2016; 11(12):e0167812. https://doi.org/10.1371/journal.pone.0167812.

4. Timmermans K. Intellectual property right and traditional medicine: policy dilemmas at the interface. Soc Sci Med. 2003;57(4):745-56.

5. Indian Village Directory. Jakholi Villages list https://villageinfo.in/uttarakhand/ rudraprayag/jakholi.html.05/06/2017.
6. Census of India. UTTARAKHAND SERIES-06 PART XII-B district census handbook Rudraprayag village and town wise primary census abstract (PCA) http:// www.censusindia.gov.in/2011census/dchb/0503_PART_B_DCHB_RUDRAPR AYAG.pdf 5/06/2017.

7. Hamilton A. Medicinal plants and conservation: issues and approaches. Medicinal Plant Conservation. 2003:9:1-51.

8. Martinez HP. Commercialisation of wild medicinal plants from southwest pueblo Mexico. Econ Bot. 1995:49:197-206.

9. Cunningham AB. Applied Ethnobotany: people, wild plant use and conservation. London: Earthscan; 2001.

10. Jain SK, Rao R. Today and tomorrow. In: A handbook of field and herbarium. New Delhi: Printers and Publishers; 1977.

11. Gaur RD. Flora of the district Garhwal northwest Himalayas (with Ethnobotanical notes). Srinagar, Garhwal: Transmedia; 1999.

12. Naithani BD. The Flora of Chamoli. Volumes 1-2. Botanical Survey of India, Howrah. 1984-1985.

13. Trotter RT, Logan MH. Informant consensus: a new approach for identifying potentially effective medicinal plants. In: Ektin NL, editor. Plants in indigenous medicine and diet, Biobehavioural approaches. Ed. Nina L. Etkin. Bedford Hills, New York: Redgrave publishers; 1986

14. Heinrich M, Ankli A, Frei B, Weimann C, Sticher O. Medicinal plants in Mexico: healers' consensus and cultural importance. Soc Sci Med. 1998;47:1859-71.

15. Gonza R, Casares M, Sanchez P, Ramiro M, Molero J, Pieroni A, Giusti E, Censorii E, de Pasquale C, Della A, Paraskeva D, Hadijchambis A, Houmani Z, El-Demerdash M, El-Zayat M, Hmamouchi M, Eljorhig S. Medicinal plants in the Mediterranean area: synthesis of the results of the project RUBIA. J Ethnopharmacol. 2008;116:341-57.

16. Sorensen TA. A method of establishing groups of equal amplitude in plant sociology based on similarity of species content and its application to analyses of the vegetation on Danish commons. 4. Kongelige Danske Videnskabernes Selskab, Copenhagen, 1948. pp. 1-34.

17. Tangjanga S, Namsa N, Arana C, Litin A. An ethnobotanical survey of medicinal plants in the eastern Himalayan zone of Arunachal Pradesh, India. J Ethnopharmacol. 2011:134:18-25.

18. Negi C, Nautiyal S, Dasila L, Rao K, Maikhuri R. Ethnomedicinal plant uses in a small tribal Community in a Part of central Himalaya. India J Hum Ecol. 2002;14(1):23-31.

19. Gazzaneo S, Lucena. Albuquerque U.P. Knowledge and use of medicinal plants by local specialists in a region of Atlantic Forest in the state of Pernambuco. J Ethnobiol Ethnomed. 2005;1:1-9.

20. Parthiban R, Vijayakumar S, Prabhu S, Yabesh J. Quantitative traditional knowledge of medicinal plants used to treat livestock diseases from Kudavasal taluk of Thiruvarur district, Tamil Nadu India. Braz J Pharmacognosy. 2016:26:109-21.

21. Shrestha PM, Dhillion SS. Medicinal plant diversity and use in the highlands of Dolakha district, Nepal. J Ethnopharmacol. 2003;86(1):81-96.

22. Singh G, Rawat GS. Ethnomedicinal survey of Kedarnath wildlife sanctuary in western Himalaya, India. Indian Journal of Fundamental and Applied Life Sciences. 2011;1(1):35-46.

23. Ghorbani A. Studies on pharmaceutical ethno botany in the region of Turk-men Sahra north of Iran (part 1): general results. J Ethnopharmacol. 2005;102:58-68.

24. Kayani S, Ahmad M, Sultana S, Shinwari ZK, Zafar M, Yaseen G, Hussain M, Bibi T. Ethnobotany of medicinal plants among the communities of alpine and sub-alpine regions of Pakistan. J Ethnopharmacol. 2015;164:186-202.

25. Islam MK, Saha S, Mahmud I, Mohamad K, Awang K, Uddin SJ, Rahman MM Shilpi JA. An ethnobotanical study of medicinal plants used by tribal and native people of Madhupur forest area. Bangladesh J Ethnopharmacol. 2014;151:921-30.

26. Bhat JA, Kumar M, Negi AK, Todaria NP. Informants' consensus on ethnomedicinal plants in Kedarnath wildlife sanctuary of Indian Himalayas. Jed Plant Res. 2013;7(4):148-54

27. Singh $H$, Husain $T$, Agnihotri $P$, Pande $P$, Khatoon $S$. An ethnobotanical study of medicinal plants used in sacred groves of Kumaon Himalaya Uttarakhand, India. J Ethnopharmacol. 2014:154:98-108.

28. Thakur M, Asrani RA, Thakur S, Sharma P, Patil R, Lal B, Parkash O. Observations on traditional usage of ethnomedicinal plants in humans and animals of Kangra and Chamba districts of Himachal Pradesh in northwestern Himalaya, India. J Ethnopharmacol. 2016:191:280-300.

29. Shah S, Ram J, Pala NA, Tripathi P, Kumar M. Medicinal plant wealth of oak dominated forests in Nainital catchment area of Uttarakhand. Academia J Med Plant. 2014;2(1):006-13. 
30. Semwal DP, Pardha Saradhi P, Kala CP, Sajwan BS. Medicinal plants used by local Vaidyas in Ukhimath block, Uttarakhand. Indian J Tradit Knowl. 2010;9(3):480-5.

31. Uniyal B, Shiva V, et al. Indian J Tradit Knowl. 2005;4(3):259-66

32. Phondani PC, Maikhuri RK, Rawat LS, Farooquee NA, Kala CP, Vishvakarma SCR, Rao KS, Saxena KG. Ethnobotanical uses of plants among the Bhotiya tribal communities of Niti Valley in central Himalaya, India. Ethnobo Res Appl. 2010;8:233-44.

33. Tewari S, Paliwal A, Joshi B. Medicinal use of some common plants among people of Garur block of district Bageshwar, Uttarakhand. India Octa J Biosci. 2014;2(1):32-5

34. Azad SA, Bhat AR. Ethno medicinal plants recorded from Rajouri-Poonch districts of J\&K state. Indian J Life Sci. 2013;2:77-9.

35. Chandra K, Nautiyal B, Nautiyal M. Herbal-based traditional medicinal knowledge of local inhabitants in Rudraprayag district of Uttarakhand. India Ethnobot Res Appl. 2013;11:299-313.

36. Samant S, Pant S, Singh M, Lal M, Singh A, Sharma A, Bhandari S. Medicinal plants in Himachal Pradesh, north western Himalaya, India. Int J Biodivers Sci Manag. 2007;3:234-51.

37. Kunwar RM, Nepal BK, Kshhetri HB, Rai SK, Bussmann RW. Ethnomedicine in Himalaya: a case study from Dolpa, Humla, Jumla and mustang districts of Nepal. J Ethnobiol Ethnomed. 2006;2:27. doi:https://doi.org/10.1186/17464269-2-27.

38. Rana CS, Tiwari JK, Danwal LR, Gairola S. Faith herbal healer knowledge document of Nanda Devi biosphere reserve Uttarakhand. India IJTK. 2013;12(2):308-14.

39. Kumari P, Joshi GC, Tewari LM. Diversity and status of ethnomedicinal plants of Almora district in Uttarakhand, India. International journal of biodiversity and conservation. 2011;3(7):298-326.

40. Rehman H, Begum W, Anjum F, Tabasum H. Rheum Emodi (rhubarb): a fascinating herb journal of Pharmacognosy and. Phytochemistry. 2014;3(2):89-94.

41. Sharma J, Gairola S, Gaur RD, Painuli RM, Siddiqi TO. Ethnomedicinal plants used for treating epilepsy by indigenous communities of subHimalayan region of Uttarakhand. India. Journal of Ethnopharmacology. 2013:150:353-70.

42. Schmeda H, Rodriguez J, Astudillo L. Gastro-protective activity of the diterpene solidagenone and its derivatives on experimentally induced gastric lesions in mice. J Ethnopharmacol. 2002;81(1):111-5.

43. Sharma J, Gairola S, Gaur RD, Painuli RM. The treatment of jaundice with medicinal plants in indigenous communities of the sub-Himalayan region of Uttarakhand, India. Journal of Ethnopharmacology. 2012;143:262-91.

44. Gairola S, Sharma J, Bedi YS. A cross-cultural analysis of Jammu, Kashmir and Ladakh (India) medicinal plant use. J Ethnopharmacol. 2014;155:925-86.

45. Kala CP. Medicinal and aromatic plants of tons watershed in Uttarakhand Himalaya. Applied ecology and environmental sciences. 2015;3(1):16-21.

46. Ghildiyal JC, Juyal P, Sadana G. Indigenous uses of plants in different women ailments in Garhwal region. Indian J Pharm Biol Res. 2014;2(1):39-44.

47. Šavikin K, Zdunić G, Menković N, Živković J, Ćujić N, Tereščenko M, Bigović D. Ethnobotanical study on traditional use of medicinal plants in southwestern Serbia, Zlatibor district. J Ethnopharmacol. 2013;146:803-10.

48. Kala CP. Herbal treatment of snakebites in Uttarakhand state of India. Indian J Nat Prod Resour. 2015;6(1):56-61.

49. Kumar M, Bussmann R, Mukesh J, Kumar P. Ethnomedicinal uses of plants close to rural habitation in Garhwal Himalaya, India. J Med Plant Res. 2011;5(11):2252-60.

50. Dangwal LR, Sharma A, Rana CS. Ethnomedicinal plants of the Garhwal Himalaya used to cure various diseases: a case study. New York Sci J. 2010; 3(12):28-31.

51. Kala CP, Farooquee NA, Majila BS. Indigenous knowledge and medicinal plants used by Vaidyas in Uttaranchal, India. Explorer Research Article. 2005;4(3):195-206.

52. Bhat JA, Kumar M, Bussmann R. Ecological status and traditional knowledge of medicinal plants in Kedarnath wildlife sanctuary of Garhwal Himalaya, India. J Ethnobiol Ethnomed. 2013;9(1):1-18.

53. Pala NA, Negi AK, Todaria NP. Traditional uses of medicinal plants of Pauri Garhwal, Uttarakhand. Nature and Science. 2010;8(6):57-61.

54. Kapkoti B, Lodhiyal N, Lodhiyal LS. Ethnomedicinal plants and their uses by ban panchayat people in Nainital of Kumaun region, Uttarakhand. Biolife Journal of biology and life science. 2014;2(2):526-32.
55. Bhatt D, Kumar R, Joshi G, Tewari L. Indigenous uses of medicinal plants by the Vanraji tribes of Kumaun Himalaya, India. J Med Plant Res. 2013;7(37):2747-54.

56. Pande N, Joshi A. Paediatric Ethnobotany of the Boxa tribe of Tarai and Bhabar region of Uttarakhand, India. International journal of scientific research. 2015;4(4):24-6.

57. Gaur R, Sharma J, Painuli R. Plants used in traditional health care of livestock by Gujjar community of sub-Himalayan tracts, Uttarakhand, India. Indian J Nat Prod Resour. 2010;1 (2):243-8.

58. Prakash R. Traditional uses of medicinal plants in Uttarakhand Himalayan region. Scholars Academic Journal of Biosciences. 2014;2(5):345-53.

59. Malik AH, Khuroo AA, Dar GH, Khan ZS. Ethnomedicinal uses of some plants in Kashmir Himalaya. Indian J Tradit Knowl. 2011;10(2):362-6.

60. IUCN, Draft IUCN Red. List Categories. Gland: IUCN. 1993.

61. CAMP (Conservation Assessment and Management Plan). Workshop Report Forest Department, UP. 1998.

62. Nayar MP, Shastry AR. Red Data Book of Indian Plants, vol. I- III, Botanical Survey of India, Calcutta. 1987,1988,1990.

63. Dhar U, Manjkhola S, Joshi M, Bhatt A, Bisht AK, Joshi M. Current status and future strategy for development of medicinal plants sector in Uttaranchal. India Current science. 2002;956(83):956-64.

64. Nautiyal MC, Nautiyal BP. Agrotechniques for high altitude medicinal \& aromatic plants. Bishen Singh Mahendra pal Singh. 2004

\section{Submit your next manuscript to BioMed Central and we will help you at every step:}

- We accept pre-submission inquiries

- Our selector tool helps you to find the most relevant journal

- We provide round the clock customer support

- Convenient online submission

- Thorough peer review

- Inclusion in PubMed and all major indexing services

- Maximum visibility for your research

Submit your manuscript at www.biomedcentral.com/submit 